\title{
A geochemical examination of humidity cell tests
}

Ann Maest ${ }^{1}$ and D. Kirk Nordstrom ${ }^{2}$

${ }^{1}$ Buka Environmental, 941 8th Street, Boulder, CO 80302, USA. 303-324-6948, aamaest@gmail.com

${ }^{2}$ U.S. Geological Survey, 3215 Marine St., Boulder, CO 80303, USA. 303-541-3037, dkn@usgs.gov

\section{Abstract}

Humidity cell tests (HCTs) are long-term (20 to $>300$ weeks) leach tests that are considered by some to be the among the most reliable geochemical characterization methods for estimating the leachate quality of mined materials. A number of modifications have been added to the original HCT method, but the interpretation of test results varies widely. We suggest that the HCTs represent an underutilized source of geochemical data, with a year-long test generating approximately 2,500 individual chemical data points. The HCT concentration peaks and valleys can be thought of as a "chromatogram" of reactions that may occur in the field, whereby peaks in concentrations are associated with different geochemical processes, including sulfate salt dissolution, sulfide oxidation, and dissolution of rock-forming minerals, some of which can neutralize acid. Some of these reactions occur simultaneously, some do not, and geochemical modeling can be used to help distinguish the dominant processes. Our detailed examination, including speciation and inverse modeling, of HCTs from three projects with different geology and mineralization shows that rapid sulfide oxidation dominates over a limited period of time that starts between 40 and 200 weeks of testing. The applicability of laboratory tests results to predicting field leachate concentrations, loads, or rates of reaction has not been adequately demonstrated, although early flush releases and rapid sulfide oxidation rates in HCTs should have some relevance to field conditions. Knowledge of possible maximum solute 
concentrations is needed to design effective treatment and mitigation approaches. Early flush and maximum sulfide oxidation results from HCTs should be retained and used in environmental models. Factors that complicate the use of HCTs include: sample representation, time for microbial oxidizers to grow, sample storage before testing, geochemical reactions that add or remove constituents, and the HCT results chosen for use in modeling the environmental performance at mine sites. Improved guidance is needed for more consistent interpretation and use of HCT results that rely on identifying: the geochemical processes; the mineralogy, including secondary mineralogy; the available surface area for reactions; and the influence of hydrologic processes on leachate concentrations in runoff, streams, and groundwater.

\section{Introduction}

Humidity cell tests (HCTs) are long-term (weeks to years) laboratory tests conducted under oxidizing conditions for estimating the leachate quality of mining materials and wastes. The tests are usually conducted before mining begins using exploration drill core rock that is expected to become waste rock or wall rock during open pit or underground mine development. The tests can be conducted on existing waste rock, tailings, or ore and have also been used to examine the leaching of oil shale, uranium, and coal extraction wastes (e.g., Essington, 1991; Hollings et al., 2001; Usher, 2009). In hardrock or metal mining settings, HCTs are conducted when the ability of the sample to produce acid drainage is uncertain, based on acid-base accounting ( $A B A$ ) tests, and to estimate the effects of long-term sulfide weathering on leachate composition. Predictions of the quality and sometimes the quantity of acid water 
discharged to receiving streams are often made based on the results of HCTs and additional hydrologic and geochemical information (INAP, 2009).

The results from HCTs represent an untapped resource of geochemical data that can be used to identify and understand geochemical processes occurring in mine waste in the laboratory and potentially in the field. A single HCT conducted for a year will have approximately 2,500 individual chemical data points if the samples are analyzed on a weekly basis for a full suite of analytes. All these data points, except those for the final weeks, are generally ignored in mine permitting evaluations. Instead, the focus has been on using "steady state" or "stable" values for mine water chemistry predictions and estimating the time to onset of acid drainage (see, e.g., Pebble Limited Partnership (PLP), 2011a; Price, 2009; SRK Consulting, 2007). Sexsmith et al. (2015) found that, for 30 samples from 14 sites, the actual times to onset of acid drainage were shorter than predicted. Stable rates are often arbitrarily defined as the average of the last five weeks of testing (Price, 2009). The results of HCTs are rarely interpreted using geochemical models. Although the American Society for Testing Materials (ASTM) method (ASTM, 2013) mentions that geochemical expertise is required for design and interpretation of the tests, no specific requirements, helpful guidelines, or expert qualifications exist at the state or federal level for conducting or especially interpreting the results of the tests. Nonetheless, the results are often relied upon to determine if water quality standards will be met and the mine can be permitted.

A number of factors can complicate the use of HCTs for estimating the consequences of mine wastes on water quality. For some mine wastes, predictions have not been precise in terms of expected concentrations or, in some cases, even qualitatively accurate in estimating near- 
neutral versus acidic conditions. In the field, the primary factors influencing leachate concentrations in seeps, streams, and groundwater are geochemical, meteorologic, and hydrologic processes. The factors that affect leachate concentrations and dissolution rates in laboratory tests compared to field conditions include the (1) test length, (2) time interval chosen from HCT results for use in predictions, (3) quantity and distribution of rock or waste samples and the degree to which they are representative of field compositions, (4) method of solid sample preparation, (5) particle size and available surface area, (6) length of storage of solid samples before testing starts, (7) time necessary for microbial oxidizers to grow, (8) geochemical reactions that may add or remove constituents, such as the formation of soluble salts and the precipitation of insoluble hydrous ferric oxides, (9) temperature, (10) humidity, (11) method of leachate application in the laboratory test, (12) method by which predictions are calculated from HCT results, (13) liquid:solid ratio in the test vs. the field, (14) preferential flow through mine wastes, (15) field climatic conditions compared to humidity cells, and (16) availability of oxygen in the field piles. Many of these issues were discussed in the review by Lapakko (2015). This paper recognizes that all the factors are important, and most of them will be mentioned, but the primary emphasis is on factors 2,8 , and 11 .

Banwart et al. (2002) created a model using laboratory results and hydrologic and geochemical scaling factors, including temperature, $\mathrm{pH}$, particle size distribution, and an estimate of preferential flow, and compared model results to field behavior at the Aitik Mine in Sweden. Sapsford et al. (2009) discussed whether HCTs accelerate weathering compared to field rates. Langman et al. (2014) presented results from carefully controlled long-term HCTs at warm and cool temperatures. Smith et al. (2013 a and b) compared results from instrumented field waste 
piles and HCTs and explored the effects of temperature, particle size, and other factors on acid generation potential but do not recommend scaling factors. Younger et al. (2002) discussed several of these factors and the calculation and application of weathering rates. Parbhakar-Fox and Lottermoser (2015) found a similar list of drawbacks for predicting the consequences of mine waste leachates from current laboratory tests. Bornhorst and Logsdon (2016) compared long-term water quality predictions using scaled results from HCTs with average recent drainage chemistry from a 52-year old test pile and also found inaccuracies in the predictions.

The main concern is how to use HCT results to better estimate field conditions. To be useful, HCT results should be reasonably similar to those from scaled-up field tests or waste rock seepage, once surface area or mass are taken into account (INAP, 2009). However, Banwart et al. (2002) noted that specific surface areas are generally not well known. Although some practitioners do estimate surface area in HCTs (e.g., Lapakko and Antonson, 2006; Lapakko and Trujillo, 2015), it is not commonly done. The ASTM (2013) method recognizes the importance of mineral surface area in determining drainage quality and recommends but does not require surface area measurements. The available surface area of acid-neutralizing and acid-generating minerals is difficult to measure in the laboratory and even more elusive under field conditions, considering that field surface areas in waste piles, for example, can change with freeze-thaw cycles, chemical weathering, and the mass of added material - all of which expose new surface areas over time. The ASTM (2013) method states that the test is not intended to simulate sitespecific leaching conditions, but it can be used to determine changes in drainage quality with 
changing composition for a rock type. ${ }^{1}$ This apparent contradiction and the lack of guidance for using laboratory results leave practitioners in a quandary.

The purpose of this study is to examine humidity cell leachate chemistry in terms of the underlying geochemical processes. This paper, in contrast to those cited above, applies geochemical modeling to the entire set of HCT data to determine how this approach might improve mine water quality prediction. To the best of our knowledge, this approach has not been taken before in publicly available literature except in two conference proceedings (Lapakko and Berndt, 2003, and Seal et al., 2015). Important questions to be addressed are whether pyrite (or other sulfide) oxidation rates can be distinguished from rates of other processes, such as secondary mineral dissolution and precipitation, and how HCT data could be used for prediction once the geochemical processes are better identified. A companion paper is planned that uses the results from scaled-up mine waste field tests, waste rock seeps, and streams receiving precipitation-event flushes to evaluate the importance of secondary mineral dissolution and other geochemical processes on the prediction of mine waste environmental behavior.

\footnotetext{
${ }^{1}$ ASTM (2013) Section 1.6 states that "This test method is not intended to provide leachates that are identical to the actual leachate produced from a solid material in the field or to produce leachates to be used as the sole basis of engineering design." And Section 1.7 states "This test method is not intended to simulate site-specific leaching conditions. It has not been demonstrated to simulate actual disposal site leaching conditions. Furthermore, the test is not designed to produce effluents that are in chemical equilibrium with the solid phase sample." However, Section 5.2 states that the "procedure can be used to address the following objectives: (1) determine the variation of drainage quality as a function of compositional variations (for example, iron sulfide and calcium+magnesium carbonate contents) within individual mine-rock lithologies, (2) determine the amount of acid that can be neutralized by the sample while maintaining drainage $\mathrm{pH} \geq 6.0$ under the conditions of the test, (3) estimate mine-rock weathering rates to aid in predicting the environmental behavior of mine rock, and (4) determine mine-rock weathering rates to aid in experimental design of site-specific kinetic tests."
} 


\subsection{The Complication of Secondary Minerals}

Secondary mineral formation accompanies sulfide mineral oxidation and it is generally of two major types: relatively insoluble hydrous oxides and hydroxysulfates (Bigham and Nordstrom, 2000), and relatively soluble metal sulfates (Jambor et al. 2000). Metal sulfate salts commonly form as efflorescent crusts on sulfide deposits and mine wastes (Nordstrom, 1982; Nordstrom and Alpers, 1999; Jambor et al., 2000) during periods of evaporation. They can also form hardpans within tailings piles (Blowes et al., 1991; McGregor and Blowes, 2002). The HCT procedure discusses the precipitation and dissolution of secondary minerals such as jarosite $\left(\mathrm{K}_{2} \mathrm{Fe}_{6}(\mathrm{OH})_{12}\left(\mathrm{SO}_{4}\right)_{4}\right)$ and melanterite $\left(\mathrm{FeSO}_{4} \cdot 7 \mathrm{H}_{2} \mathrm{O}\right)$ that can form from the weathering of $\mathrm{Fe}$ sulfides (ASTM, 2013), the mineralogy of the salts is rarely included in mine waste characterization studies, and the behavior of these and other metal sulfate salts is largely ignored when interpreting HCT results. Downing (2014) discussed the contribution of soluble salts to HCT results from Keno Hill (Yukon Territory) and Huckleberry (British Columbia) semiquantitatively, but the Keno Hill samples were run for only 30 weeks and a Huckleberry aerated sample did not produce acid after 125 weeks.

According to Price (2009), HCTs generally do not simulate conditions that produce secondary weathering products, even though these oxidation products can control drainage chemistry in the field. In fact, the updated ASTM (2013) HCT method notes that three to five weekly flushes are needed to remove pre-existing soluble oxidation salts from the samples, and caution should be used in interpreting mass release rates during those weeks (ASTM, 2013). Some of the more common soluble salts are gypsum, melanterite, rozenite, copiapite, and halotrichite. The association of various soluble salts with their co-existing acid solution has been demonstrated 
in the lab (Alpers et al., 1994) and in the field (Nordstrom and Alpers, 1999; Jamieson et al., $2005 a, b)$. Secondary sulfate salts containing Fe or Al can store acidic metal-rich mine drainage in solid form until they are dissolved by the next rainstorm or snowmelt event. Upon dissolution in the field, acidity and high metal and sulfate concentrations reappear (Hammarstrom et al., 2005).

\section{Study Sites}

The HCT results selected for this study are from one active mine and two proposed mining projects in the United States. The geologic settings span a range of rock and mineralization types including a granodioritic intrusion (Pebble), a metamorphosed sedimentary and volcanic deposit (Buckhorn), and a mafic intrusion (PolyMet) (Table 1). 
Table 1. Humidity cell test sample descriptions and modification from ASTM (2013) method

\begin{tabular}{|c|c|c|c|c|c|c|c|c|c|c|}
\hline $\begin{array}{l}\text { Mine or Project Site } \\
\text { Name, Location, } \\
\text { Commodity }\end{array}$ & $\begin{array}{l}\text { Sample ID } \\
\text { (test type) }\end{array}$ & Rock Type & $\begin{array}{l}\text { Aged } \\
\text { before } \\
\text { Testing } \\
\text { (yrs) }\end{array}$ & $\begin{array}{l}\text { Percent } \\
\text { Sulfur } \\
\text { (Total/ } \\
\text { Sulfide) }\end{array}$ & NP:AP & $\begin{array}{l}\text { Test } \\
\text { Length } \\
\text { Days }\end{array}$ & $\begin{array}{l}\text { Lowest } \\
\text { HCT pH }\end{array}$ & $\begin{array}{l}\text { Sample } \\
\text { Mass, } \\
\text { HCT Cell } \\
\text { (kg) }\end{array}$ & $\begin{array}{l}\text { Leach } \\
\text { Water } \\
\text { Applied } \\
(\mathrm{mL})\end{array}$ & Modifications from ASTM \\
\hline \multirow[t]{9}{*}{$\begin{array}{l}\text { Pebble Project, } \\
\text { Alaska; Pebble } \\
\text { West/Copper-gold }\end{array}$} & $\begin{array}{l}025-0617- \\
0637 \text { (HCT) }\end{array}$ & $\begin{array}{l}\text { Pre-Tertiary/ } \\
\text { Diorite }\end{array}$ & $13-16$ & $3.56 / 3.37$ & 0.09 & 203 & 4.03 & 5 & 2500 & $\begin{array}{l}5 \text { not } 1 \mathrm{~kg} \text {; particle size } 9.5 \text { not } \\
6.3 \mathrm{~mm} \text {; trickle leach; } 2500 \text { not } \\
500-1000 \mathrm{~mL} \text { water }\end{array}$ \\
\hline & $\begin{array}{l}\text { 3069-0927- } \\
0947 \text { (HCT) }\end{array}$ & $\begin{array}{l}\text { Pre-Tertiary/ } \\
\text { Granodiorite }\end{array}$ & $2-3$ & $2.48 / 2.44$ & 0.04 & 2072 & 2.41 & 5 & 2500 & Same as 025-0617-0637 \\
\hline & ARLB001 & Pre-Tertiary & $<1$ & $5.33 / 5.16$ & 0.04 & 994 & 2.92 & 1 & 500 & HCTs used material subsampled \\
\hline & $\begin{array}{l}\text { ARLB002 } \\
\text { (HCTs for field } \\
\text { barrel test) }\end{array}$ & $\begin{array}{l}\text { Pebble West } \\
\text { metasedi- } \\
\text { mentary } \\
\text { mudstone }\end{array}$ & & $\begin{array}{l}5.15 / 4.97 \\
\text { (mean of } \\
2 \text { sub- } \\
\text { samples) }\end{array}$ & $\begin{array}{l}0.04 \\
\text { (mean of } \\
2 \text { sub- } \\
\text { samples) }\end{array}$ & & 2.59 & & & $\begin{array}{l}\text { from field barrel tests after } 3 \text { mo } \\
\text { of testing; followed ASTM } \\
\text { sample weights and leach water } \\
\text { volumes }\end{array}$ \\
\hline & ARLB003 & Pre-Tertiary & $<1$ & $3.96 / 4.77$ & 0.18 & 980 & 6.85 & 1 & 500 & Same as ARLB001 and 002 \\
\hline & $\begin{array}{l}\text { ARLB006 } \\
\text { (HCTs for field } \\
\text { barrel test) }\end{array}$ & $\begin{array}{l}\text { Pebble West } \\
\text { granodiorite/ } \\
\text { diorite/ mon- } \\
\text { zonite }(2: 1: 1)\end{array}$ & & $\begin{array}{l}2.79 / 2.54 \\
\text { (mean of } \\
2 \text { sub- } \\
\text { samples) }\end{array}$ & $\begin{array}{l}0.35 \\
\text { (mean of } \\
2 \text { sub- } \\
\text { samples) }\end{array}$ & & 7.52 & & & \\
\hline & ARLB001 & Pre-Tertiary & $<1$ & Same as & Same as & 763 & 4.35 & Up to & variable & 200-L barrels filled with \\
\hline & $\begin{array}{l}\text { ARLB002 } \\
\text { (field barrel) }\end{array}$ & $\begin{array}{l}\text { Pebble West } \\
\text { metasedi- } \\
\text { mentary } \\
\text { mudstone }\end{array}$ & & $\begin{array}{l}\text { ARLB001 } \\
\text { / } 002 \\
\text { HCTs }\end{array}$ & $\begin{array}{l}\text { ARLB001 } \\
\text { / } 002 \\
\text { HCTs }\end{array}$ & & 4.16 & 250 & & $\begin{array}{l}\text { composited low-grade rock, } \\
\text { open on top; grain size }<5.1 \mathrm{~cm} \\
(70 \%>9.5 \mathrm{~mm}) ; \text { rain water/snow } \\
\text { melt applied as available in field }\end{array}$ \\
\hline & $\begin{array}{l}\text { ARLB003 } \\
\text { ARLB006 } \\
\text { (field barrel) }\end{array}$ & $\begin{array}{l}\text { Pre-Tertiary } \\
\text { Pebble West } \\
\text { granodiorite/ } \\
\text { diorite/ mon- } \\
\text { zonite (2:1:1) }\end{array}$ & $<1$ & $\begin{array}{l}\text { Same as } \\
\text { ARLB003 } \\
\text { / } 006 \\
\text { HCTs }\end{array}$ & $\begin{array}{l}\text { Same as } \\
\text { ARLB003 } \\
\text { / } 006 \\
\text { HCTs }\end{array}$ & 731 & $\begin{array}{l}6.95 \\
5.2\end{array}$ & $\begin{array}{l}\text { Up to } \\
250\end{array}$ & variable & $\begin{array}{l}200-\mathrm{L} \text { barrels filled with } \\
\text { composited low-grade rock, } \\
\text { open on top; grain size }<5.1 \mathrm{~cm} \\
(84 \%>9.5 \mathrm{~mm}) \text {; rain water/snow } \\
\text { melt applied as available in field }\end{array}$ \\
\hline
\end{tabular}

Page 9 


\begin{tabular}{|c|c|c|c|c|c|c|c|c|c|c|}
\hline $\begin{array}{l}\text { Mine or Project Site } \\
\text { Name, Location, } \\
\text { Commodity }\end{array}$ & $\begin{array}{l}\text { Sample ID } \\
\text { (test type) }\end{array}$ & Rock Type & $\begin{array}{l}\text { Aged } \\
\text { before } \\
\text { Testing } \\
\text { (yrs) }\end{array}$ & $\begin{array}{l}\text { Percent } \\
\text { Sulfur } \\
\text { (Total/ } \\
\text { Sulfide) }\end{array}$ & NP:AP & $\begin{array}{l}\text { Test } \\
\text { Length } \\
\text { Days }\end{array}$ & $\begin{array}{l}\text { Lowest } \\
\text { HCT pH }\end{array}$ & $\begin{array}{l}\text { Sample } \\
\text { Mass, } \\
\text { HCT Cell } \\
(\mathrm{kg})\end{array}$ & $\begin{array}{l}\text { Leach } \\
\text { Water } \\
\text { Applied } \\
(\mathrm{mL})\end{array}$ & Modifications from ASTM \\
\hline \multirow[t]{2}{*}{$\begin{array}{l}\text { Buckhorn Mine, } \\
\text { Washington; Gold } \\
\text { Bowl/Gold }\end{array}$} & $\begin{array}{l}\text { HC-1 GB-C13- } \\
419 \text { (HCT) }\end{array}$ & $\begin{array}{l}\text { Magnetite } \\
\text { skarn }\end{array}$ & $1.5-2$ & $4.72 / 1.91$ & 0.08 & 1176 & 2.34 & 1.52 & 750 & $\begin{array}{l}\text { Higher sample weight and water } \\
\text { volume, 6.3-mm grain size; flood } \\
\text { leach }\end{array}$ \\
\hline & $\begin{array}{l}\text { HC-8 GB-C13- } \\
342 \text { (HCT) }\end{array}$ & Garnet skarn & $1.5-2$ & $2.72 / 0.87$ & 0.19 & 1176 & 2.39 & 1.50 & 750 & Same as HC-1 \\
\hline \multirow[t]{3}{*}{$\begin{array}{l}\text { PolyMet Project, } \\
\text { Minnesota/Copper- } \\
\text { nickel-PGE }\end{array}$} & $\begin{array}{l}337 \mathrm{C}(510- \\
520)(\mathrm{HCT})\end{array}$ & Virginia $\mathrm{Fm}^{1}$ & NA & $5.12 / \mathrm{ND}$ & $\begin{array}{l}<0.05 \% \mathrm{C} \\
<0.02 \\
\% \mathrm{CO}_{2}\end{array}$ & 1386 & 3.24 & 1.0 & $750 / 500$ & $\begin{array}{l}\text { Cells were } 10.2-\mathrm{cm} \text { ID x } 30.5-\mathrm{cm} \\
\mathrm{H} \text { (not } 20.3-\mathrm{cm} \mathrm{H} \text { ); bulk samples } \\
\text { split differently, particle size } \\
\text { distribution different than ASTM; } \\
\text { peristaltic pump, not separatory } \\
\text { funnel for flood leach; } 500 \mathrm{~mL} \text {, } \\
\text { flood leach; week } 0 \text { rinse volume } \\
\text { was } 750 \mathrm{ml} \text { not } 500 \mathrm{ml} \text {. }\end{array}$ \\
\hline & $\begin{array}{l}367 \mathrm{C}(400- \\
405)(\mathrm{HCT})\end{array}$ & Troctolitic & NA & $1.52 / N D$ & $\begin{array}{l}0.05 \% \mathrm{C} \\
0.2 \% \mathrm{CO}_{2}\end{array}$ & 1386 & 3.65 & 1.0 & $750 / 500$ & Same as $337 C(510-520)$ \\
\hline & $\begin{array}{l}\text { 26027(616- } \\
626)(\mathrm{HCT})\end{array}$ & $\begin{array}{l}\text { Anorthositic } \\
\text { troctolite }\end{array}$ & NA & $1.83 / \mathrm{ND}$ & $\begin{array}{l}0.05 \% \mathrm{C} \\
0.2 \% \mathrm{CO}_{2}\end{array}$ & 2359 & 3.63 & 1.0 & $750 / 500$ & Same as $337 C(510-520)$ \\
\hline
\end{tabular}

$\mathrm{NP}: \mathrm{AP}=$ neutralization potential to acid-generation potential ratio; 1 Virginia Fm = argillite and greywacke with minor interbeds of siltstone, graphitic argillite, chert, and carbonate; ND = not determined; NA = not analyzed. Primary sources: Pebble - PLP, 2011a; Buckhorn - Golder Associates, Inc. 2005 and 2006 ; PolyMet - SRK Consulting, 2007. Available links provided in reference section. 
Pebble Project, Alaska. The Pebble copper-gold-molybdenum porphyry deposit in southwestern Alaska is one of the largest undeveloped copper deposits in the world. The ore body is hosted in pre-Tertiary granodiorite (Pebble West) and granodiorite and siliciclastic sedimentary rocks (Pebble East); the mineralization in Pebble East is higher grade and deeper than in Pebble West (Wardrop, 2011). The dominant sulfide minerals are pyrite, chalcopyrite (dominant copper mineral in both zones; Lang et al., 2013), and molybdenite with minor bornite, chalcocite, and tetrahedrite; the dominant aluminosilicate minerals in granodiorite samples were K-feldspar and sericite, no siderite was identified, and biotite was largely replaced by muscovite and sericite (PLP, 2011a; Wardrop, 2011). The ore body, especially in the pre-Tertiary granodiorite sections, generally has low acid-neutralization potential. The surrounding Tertiary rocks are largely non-acid-generating. The Pebble West deposit has an oxide cap (<30.5 $\mathrm{m}$ thick) underlain by a supergene zone containing chalcocite, covellite, and some chalcopyrite. Pebble East has hypogene mineralization and no oxide cap. Over 1,000 acidbase accounting tests, 84 HCTs, and 120 short-term leach tests were conducted in prepermitting studies (PLP, 2011a, b), and over 7,000 whole rock metal analyses were used to delineate the ore body (Wardrop, 2011). Mineralogic analysis was conducted on 30 HCT residue samples after humidity cell testing (PLP, 2011a; Appendix 11E).

Buckhorn Mine, Washington. The Buckhorn Mine is an active underground gold mine in northcentral Washington State that started operation in January 2008; mine closure is expected in 2017. The gold ore is shipped to Republic, Washington, for beneficiation and processing using milling, flotation, and carbon-in-pulp methods. The deposit is hosted in andesite, skarns, clastic rocks, and marble with moderate to substantial acid-neutralization potential (Hickey, 1992). 
Pyrrhotite is the most common sulfide mineral (90-95\% is pyrrhotite; Kea Pacific Holding, Inc., 1993), with minor amounts of chalcopyrite, bismuthinite, arsenopyrite, and pyrite, and trace amounts of molybdenite, galena, sphalerite, and joséite $\left(\mathrm{Bi}_{4} \mathrm{Te}_{2} \mathrm{~S}\right)$ (Hickey, 1990 and 1992; Washington State Department of Ecology, 2005). Geochemical testing before mining began included 42 HCTs, 385 acid-base accounting, 89 whole rock, and 77 short-term leach tests (using U.S. E.P.A.'s synthetic precipitation leaching procedure) (Washington State Department of Ecology, 2005). The majority of the ABA samples were non-acid producing, although 12 of the $42 \mathrm{HCTs}$ produced acid after 15 weeks. Elevated concentrations of nitrate, $\mathrm{SO}_{4}$, and chloride relative to background conditions have been observed in streams and groundwater downgradient of the mine (Washington State Department of Ecology, 2014).

PolyMet Project, Minnesota. The PolyMet copper-nickel-platinum group element deposit is contained in layered mafic (troctolitic - with plagioclase, olivine, and minor pyroxene) intrusions in the Duluth Complex (Ripley and Alawi, 1986). Some ultramafic units are also present in the complex. The mineralization is present as both disseminated and as massive sulfides, with Cu-Ni-Fe sulfides. Pyrrhotite mineralization also occurs in the sedimentary Virginia Formation, composed of argillite and greywacke, which is in direct contact with one of the layered intrusions (MDNR et al., 2013). In the non-reactive waste rock (designated as $\leq 0.05 \% \mathrm{~S}$ ), the order of decreasing abundance of sulfide minerals is chalcopyrite, pyrrhotite, pentlandite $\left.\left[(\mathrm{Ni}, \mathrm{Fe})_{9} \mathrm{~S}_{8}\right)\right]$, cubanite $\left(\mathrm{CuFe}_{2} \mathrm{~S}_{3}\right)$, and bornite (no pyrite). The primary silicates are plagioclase and olivine. For the reactive waste rock samples (initially defined as $\geq 0.05 \% \mathrm{~S}$ ), the dominant sulfide is pyrrhotite, followed by chalcopyrite, pentlandite, and cubanite (SRK Consulting, 2007). Historical iron mining under the Duluth Complex took place starting in the 1960s (Lapakko et 
al., 2001). PolyMet conducted 92 ASTM HCTs and 20 kinetic tests using a methodology developed by the MDNR (SRK Consulting, 2007). Some of the tests were ongoing for over eight years and are among the longest-lasting HCTs. Acid-base accounting testing and whole rock analyses were conducted on 61 waste rock and 24 lean ore samples. Field testing included six 1000-ton test piles started in 1977 (from AMAX shaft cores) and monitoring of leachate from the Dunka Pit stockpiles (waste rock removed to access the iron formation). Mineralogy was examined in 58 samples, but sulfate minerals were not examined (SRK Consulting, 2007, Appendix D.1, Optical Mineralogy Report, produced by PolyMet). Up to 98 percent of the rocks were identified as adcumulates (accumulations of minerals formed in the melt that sink with gravity) with plagioclase and olivine as the primary phases. Up to 98 percent of the sulfides occur among the cumulate phases, and up to 5 percent occur in silicates (SRK Consulting, 2007).

\section{Methods}

\subsection{Selection of study sites and HCT samples}

The mining sites were chosen based on the availability of electronic HCT data and the familiarity of the authors with the sites. For this study, we selected HCT samples that covered a range of geology and mineralogy and a range of metal, major ion, minor and trace element HCT concentrations, and $\mathrm{pH}$ values. All leachate samples were filtered through $0.45-\mu \mathrm{m}$ pore size filters. Sufficient water chemistry was available to compute speciation and to apply inverse modeling. Iron (II/III) concentrations were not determined, only total dissolved Fe. We also looked for HCTs that were conducted over long enough periods of time to show acid generation, if it was going to occur. Samples with Eh or oxidation-reduction potential (ORP) 
results were favored for geochemical modeling so that Fe(II/III) could be estimated for acidic samples and saturation indices calculated for secondary Fe minerals (Nordstrom, 2011). The sites and samples selected were not meant to provide a broad overview of all possible HCT outcomes. Rather the focus of this study is to examine geochemical behavior in HCTs. The samples were also selected to examine the early stages of acid drainage formation when $\mathrm{pH}$ values begin to drop.

The Pebble deposit samples were selected because they have low acid neutralizing capacity and moderate sulfide percentages (Table 1), and pyrite is the dominant sulfide mineral. Pebble samples contained more copper than those from the other two deposits, and we wanted to examine the behavior of metals other than Fe in the HCTs, especially in the dissolution of secondary salts. The Buckhorn Mine samples are from lithologies (skarns) that should contain carbonate minerals, but the neutralization potential to acid-generation potential (NP:AP) ratios were also quite low. The dominant sulfide mineral at the Buckhorn Mine is pyrrhotite rather than pyrite. The PolyMet deposit is on the opposite end of the lithologic spectrum from the Pebble deposit and is dominated by mafic and some ultramafic lithologies. Whereas some pyrite is present in the Buckhorn deposit, no pyrite was identified in the PolyMet samples. The PolyMet samples provide an opportunity to examine neutralization by silicate minerals, especially plagioclase and olivine. The samples also cover a range of storage time and oxidation before testing began (Table 1). 


\subsection{Evaluation of HCT Methods and Modifications and Selection of HCTs}

Information about the humidity cell leachate methods used and the HCT results themselves were derived from publicly accessible documents and files for each of the three sites. The primary sources of information are listed in Table 1, and links to the reports and data are included in the references. This section includes a brief description of the ASTM (2013) HCT method and the modifications used for the samples evaluated.

The HCT was designed to accelerate or enhance the weathering of mine wastes and ore samples to allow for the convenient production and collection of solubilized weathering products (ASTM, 2001, 2013). The acceleration is achieved by grinding the sample material to a consistently small particle size (6.3-mm, or $0.25-\mathrm{in}$.) and by pumping dry and humidified air through the column containing the sample. In the most commonly used option (Option A), dry air is pushed up through the 1-kg sample for three days, followed by three days of humidified air (approximately 95 percent relative humidity). The dry air evaporates some interstitial water remaining from the previous water leach and is intended to ensure that molecular oxygen is not a limiting factor. Humid air would promote microbial oxidation of Fe sulfides (Nordstrom and Southam, 1997), but the published method makes no mention of biotic interactions. The test

officially begins with the first deionized water leach, which previously involved either flooding the column with water ("flood leach" over approximately $1 \mathrm{hr}$ ) or trickling water through the column ("trickle leach" over an approximately 2-3 $\mathrm{hr}$ period) (ASTM, 2001). The revised ASTM (2013) method identifies flood leaching as the preferred approach. The amount of water used can be either 500 or $1,000 \mathrm{~mL}$. The original ASTM HCT method (ASTM, 1996) recommended a 
testing length of 20 weeks; the more recent versions (ASTM, 2007 and 2013) do not define a specific test length (SME, 2014) but do mention measuring solutes weekly for at least the first two weeks and measuring solutes every other week until week 20 and less frequently thereafter. Nevada's office of the Bureau of Land Management recommended that 20 weeks should be the minimum testing period (Bureau of Land Management, 2013), and a Mine Environment Neutral Drainage (MEND) publication recommends continuing the tests until $\mathrm{SO}_{4}$ and metal leaching rates stabilize for at least five weeks, which could take from 40 to over 60 weeks or several years (Price, 2009). The most recent description of static and kinetic tests, including HCTs with detailed procedures, their modifications, their interpretation, and examples is found in Williams and Diehl (2014). In addition to an overview of prediction methods and their evaluation, the volume includes introductory chapters on the context of the tests and acid drainage.

Modifications to the ASTM HCT method can affect the leaching rate, concentrations observed, and the length of time until the sample generates acid or leaches other constituents. Table 1 shows the deviations from the ASTM method used for tests examined for each of the three locations.

\subsection{Graphing HCT results}

Results from HCTs are typically presented in concentrations as $\mathrm{mg} \mathrm{L}^{-1}$ or as rates in $\mathrm{mg} \mathrm{kg}^{-1} \mathrm{wk}^{-1}$, and the results are plotted by constituent (e.g., $\mathrm{SO}_{4}$ ) for all samples (i.e. the $\mathrm{SO}_{4}$ results for all samples will be presented on the $\mathrm{SO}_{4}$ plot). Plotting different constituents on the same graph in molar units allows for more direct comparisons of the relative importance of major cations and 
anions over time and for improved evaluations of geochemical behavior of related constituents over the course of the test. We plotted constituents together that conveyed information about geochemical reactions occurring during the test. In general, plots used to examine the dissolution of secondary salts included measured molar concentrations of $\mathrm{Ca}, \mathrm{Mg}, \mathrm{SO}_{4}$, and sometimes $\mathrm{Na}, \mathrm{Cl}$, and $\mathrm{Cu}$. The Pebble samples had elevated $\mathrm{Cu}$ concentrations in early-flush leachate. Plots used to examine redox behavior included $\mathrm{pH}$, Eh, Fe (total and speciated concentrations), and the ferrihydrite saturation index (SI; Nordstrom and Munoz, 1994).

\subsection{Geochemical modeling using WATEQ4F}

\subsubsection{Charge imbalance and conductivity balance}

The geochemical program WATEQ4F (Ball and Nordstrom, 1991; with database updates) was used to evaluate the leachate results from the HCT samples. Results were entered into WATEQ4F, and the output was examined for charge and conductivity balances. Speciated charge imbalances (Cls) in WATEQ4F are calculated according to the equation:

$$
C I=\frac{\sum m e q L_{\text {cations }}^{-1}-\sum m e q L_{\text {anions }}^{-1}}{\left(\sum m e q L_{\text {cations }}^{-1}+\sum m e q L_{\text {anions }}^{-1}\right) / 2} \times 100
$$

If the $\mathrm{Cl}$ was greater than \pm 20 to $25 \%$ (Nordstrom et al., 2009), the direction of the $\mathrm{Cl}$ (positive or negative for the $\mathrm{Cl})$ and the conductivity imbalance $\left(\delta \mathrm{K}_{25}\right.$; comparing measured and WATEQ4F-calculated conductivity values, also positive or negative) were examined to determine if cations or anions needed to be adjusted, and in which direction. Because we did not collect or analyze the samples, the more liberal acceptance rates will be applied. The $\delta K_{25}$, 
or the difference between the measured and calculated conductivity at $25^{\circ} \mathrm{C}\left(\mathrm{K}_{25}\right.$ calculated and $\mathrm{K}_{25}$ measured), is calculated as:

$$
\delta K_{25}=\frac{\left(K_{25 \text { calculated }}-K_{25} \text { measured }\right)}{K_{25} \text { measured }} \times 100
$$

Using the protocols established by McCleskey et al. (2011), the dominant cation or anion was adjusted, and the program was re-run until charge imbalances met the criteria. In one case, the major cation appeared to be off by an order of magnitude, which suggests a decimal-place entry error; the reported concentration was lowered accordingly, and $\mathrm{Cl}$ values were within acceptable limits (<25\%). Measured ORP values were available for all samples selected for the $\mathrm{Cl}$ and $\delta \mathrm{K}_{25}$ evaluation. Using measured ORP or adjusted Eh values as WATEQ4F input values, Fe aqueous species and saturation indices were calculated in WATEQ4F. Uncertainties in Eh values could affect results for Fe speciation and saturation indices. Results from WATEQ4F for Fe species concentrations and saturation indices were plotted to evaluate the oxidation of sulfide minerals in the HCTs.

\subsubsection{Fe(II) and Fe(III) redox species}

Unfortunately, determinations of dissolved Fe (II) and Fe (III) were not obtained directly in these studies. Iron mineral solubility is critical to interpreting the changing chemical conditions during an $\mathrm{HCT}$. The complexing of $\mathrm{SO}_{4}$ with $\mathrm{Fe}$ (II) is weaker than that for Fe (III) and changes the interactions with other ions. The concentration of Fe (II) in natural waters is much greater than Fe (III) except at low pH values (generally <3). A precipitated Fe (III) phase can sorb trace elements and coat sulfide mineral grains, thus slowing the oxidation rate. Increased concentrations of the strong oxidant Fe (III) will increase the rate of sulfide mineral oxidation. 
Hence, to understand the dominant reactions controlling leachate chemistry during these tests, it is necessary to have data on Fe (II) and Fe (III) concentrations.

For leachate with $\mathrm{pH}$ values $<4$, a quantitative relation exists between the ORP and the Fe(II/III) concentrations based on the Nernst equation (Nordstrom et al., 1979; Nordstrom, 2011;

Nordstrom and Campbell, 2014). On this basis, it was possible to estimate the Fe(II) and Fe(III) concentrations using WATEQ4F. Although the estimates should be considered semiquantitative, they make possible important interpretations that depend on knowing when Fe(II) and Fe(III) predominate in the tests.

Measured ORP values were available for all selected samples. However, information on the type of electrode used, the type of reference electrode, and the reference electrode solution was usually not available. The ORP was assumed not to have been corrected to Eh (electrode potential relative to the standard hydrogen electrode), and a value of $200 \mathrm{mV}$ (roughly equivalent to the $\mathrm{Ag} / \mathrm{AgCl}$ half-cell potential) was added to the potentials as an approximate correction. Making this correction was found to improve the saturation indices for ferrihydrite and bring them closer to the equilibrium value. Using ORP adjusted to Eh values as WATEQ4F input values, Fe aqueous redox species and saturation indices were calculated.

\subsection{Calculation of oxidation and dissolution rates}

Data from WATEQ4F output were used to plot concentrations of total dissolved Fe and Fe species (sum of Fe(II) species, sum of Fe(III) species), and ferrihydrite SI values, and WATEQ4F input data were used to plot $\mathrm{pH}$, Eh, and $\mathrm{SO}_{4}$ concentrations for Pebble Project sample 30690927-0947, Buckhorn Mine sample HC-1, and PolyMet Project sample 26027(616-626). These 
samples were chosen because $\mathrm{pH}$ values dropped to 4.0 or lower, which resulted in measurable concentrations of both $\mathrm{Fe}(\mathrm{II})$ and $\mathrm{Fe}(\mathrm{III})$ and notable increases in dissolved Fe and $\mathrm{SO}_{4}$ concentrations. Spreadsheets were used to calculate the maximum rate of Fe sulfide oxidation using the change in dissolved Fe species and $\mathrm{SO}_{4}$ concentrations, over the time that both $\mathrm{Fe}$ and $\mathrm{SO}_{4}$ concentrations were increasing rapidly, taking the volume of leachate solution into account. Mineralogic information, as available, and measured molar concentrations of $\mathrm{Fe}, \mathrm{Cu}$, and $\mathrm{SO}_{4}$ were used to infer the most likely sulfide minerals responsible for the observed changes in concentration. For samples with $\mathrm{SO}_{4}$ molar concentrations that far exceed $\mathrm{Fe}$ concentrations (on a stoichiometric basis, depending on known Fe sulfide minerals in the sample), and where there is an indication of sulfate salt dissolution, the major cation molar concentrations (especially $\mathrm{Ca}$, for gypsum) were subtracted from the $\mathrm{SO}_{4}$ concentrations (assuming a 1:1 molar ratio) to "unmask" the increase in $\mathrm{SO}_{4}$ that is related to sulfide oxidation (Price, 2009). In addition, maximum and "steady state" $\mathrm{Fe}$ and $\mathrm{SO}_{4}$ release rates were calculated using the measured $\mathrm{HCT}$ Fe and $\mathrm{SO}_{4}$ concentrations (in $\mathrm{mg} \mathrm{L}^{-1}$ ), the volume of aqueous sample (in L), and the mass of solid sample (in $\mathrm{kg}$, see Table 1), to arrive at $\mathrm{Fe}$ and $\mathrm{SO}_{4}$ release rates, in $\mathrm{mg} \mathrm{kg}^{-1} \mathrm{wk}^{-1}$, over the weeks with the most rapid sulfide dissolution and the most stable Fe and $\mathrm{SO}_{4}$ concentrations. Because Fe concentrations were lower due to precipitation of $\mathrm{Fe}$ oxyhydroxide, $\mathrm{SO}_{4}$ was used for all comparisons. A similar approach was used to calculate maximum early flush rates. Rates were calculated per mass of total material in the HCT (see Table 1) and for the amount of Fe sulfide in the HCT sample, assuming that pyrite and pyrrhotite were the most common Fe sulfides in the Pebble and Buckhorn/PolyMet samples, 
respectively. Measured rates were compared to known rates of oxidation of sulfide minerals from laboratory experiments.

"Early flush" is a term we are using to describe the early portion of the HCTs wherein soluble salts tend to get flushed out and that usually begins before sulfide mineral oxidation. The process is similar to the "first flush" described by Nordstrom (2009) and references therein that occurs when heavy rainfall follows a long dry period and dissolution of soluble salts causes an increase in acid solutes from mine wastes in surface waters.

\subsection{Salt dissolution: preliminary review and inverse modeling using PHREEQC}

As a preliminary review, early flush HCT results for the Pebble Project, the Buckhorn Mine, and the PolyMet Project samples were evaluated using WATEQ4F and hand calculations to help determine the possible secondary salts responsible for elevated solute concentrations early in the HCTs. The following sample IDs and weeks were examined: for the Pebble Project, samples 025-0617-0637 week 0 and 3069-0927-0947 week 0; for the Buckhorn Mine, samples HC-1 week 1 and HC-8 week 0; and for the PolyMet Project, samples 337C(510-520) week 10, $367(400-405)$ week 2 , and $26027(616-626)$ week 2 . The weeks examined were those with the highest $\mathrm{SO}_{4}$ concentrations ("early flush") in roughly the first 50 weeks of testing. The HCT results for these samples were run in WATEQ4F, and the balance between cations and ions were compared (any with concentrations $\geq 10^{-5} \mathrm{~m}$ ). Molar concentrations were converted to equivalents, and the proportion of the anions that the major and minor cations could account for were evaluated by incrementally adding cations, in order of decreasing abundance (e.g., for a sample with $\mathrm{SO}_{4}>>\mathrm{Cl}$ and $\mathrm{Na}>\mathrm{Ca}$, the $\mathrm{Na} / \mathrm{SO}_{4}$ equivalents (as a percentage) were calculated, 
then $\mathrm{Ca}$ was added to $\mathrm{Na}$ and compared to the $\mathrm{SO}_{4}$ equivalents. The secondary salts with $\mathrm{SI}$ values close to or $>0$ were also considered.

The inverse modeling routine of PHREEQC (Parkhurst and Appelo, 2013) was used to estimate the moles of dissolved minerals needed to produce the observed solute concentrations in earlyflush HCT samples. The same HCT samples used for calculation of oxidation rates described in Section 3.5 were used for inverse modeling. Measured HCT concentrations were initially input to WATEQ4F, and Cls were corrected using the approach of McCleskey et al. (2011). The only samples requiring charge balancing were weeks 0 and 10 of the Buckhorn sample, and week 10 of the PolyMet sample.

Measured major and minor solute concentrations, including metals if present in concentrations $\geq 10^{-5} \mathrm{~m}$, from the following HCT weeks were evaluated using inverse modeling: Pebble sample 3069-0927-0947 - weeks 1, 2, and 4; Buckhorn sample HC-1 - weeks 0, 1, 3, 5, and 10; and PolyMet sample 26027(616-626) - weeks 0, 2, and 4. Uncertainty was set at 1.0 , and the WATEQ4F thermodynamic database was used because it has hydrated sulfate salts. Possible sulfate, chloride, oxide, and carbonate minerals dissolving were selected in the inverse modeling program based on the available phases in PHREEQC (NETPATH) and known field occurrences from the literature; choices also needed to be consistent with the solution chemistry, and the SI values from WATEQ4F were used as a guide. The solution chemistry did not indicate that aluminosilicate minerals were dissolving substantially during early-flush times. The inverse modeling output included the speciation and saturation indices and the number of moles of selected phases dissolving and precipitating. 


\section{Results and Discussion}

\subsection{Modifications of ASTM method}

Table 1 lists the ASTM method modifications used for HCT samples from the Pebble Project, the Buckhorn Mine, and the PolyMet Project. The Pebble Project HCTs were the only ones to use trickle leach; Buckhorn and PolyMet used flood leaching. The Pebble HCTs had the highest measured ORP values and were the only tests in which the WATEQ4F-calculated Fe(III) dominated over Fe(II) species for the majority of the test (discussed in Section 4.3). The Pebble HCT procedure also used five times as much material called for in the ASTM method and five times the solution volume applied to the columns. The Buckhorn HCTs also used higher sample mass and leachate volume (1.5 times ASTM methods). Although the liquid:solid ratio remained the same with these increases, edge effects and preferential pathways in the larger columns could be important and affect leachate chemistry (Tremblay and Hogan, 2000). The ASTM method recommends using cells with an inside diameter of 4.0 inches $(10.2 \mathrm{~cm})$ and a height of 8.0 inches $(20.3 \mathrm{~cm})$ for coarser particles (100\% passing a $6.3-\mathrm{mm} / 1 / 14$-inch screen). The dimensions of the columns were not reported for the Pebble or Buckhorn samples. Tremblay and Hogan (2000) recommended using a column diameter to largest particle size ratio of $\geq 6$ to avoid channeling of solution along the column walls. Channeling would result in incomplete contact of the leachate solution with the material in the column and affect mine water quality predictions.

The Pebble HCT particle size was larger than that recommended in the ASTM method (which is 100 percent passing $1 / 4$-inch or $6.3-\mathrm{mm}$ screen): PLP (2011c) listed the particle size as 1 inch 
$(2.54 \mathrm{~cm})$, but PLP (2011a) stated that the particle size was 3/8 inch $(9.5 \mathrm{~mm})$; either is larger than the recommended size. The explanation given in the sampling plan for using the larger particle size was that the mineralization occurs in veinlets, and the coarser particle size would allow greater exposure of mineralization on fracture faces results from blasting (PLP, 2011c) . No information on the size of the veinlets was provided, but if they are only liberated (exposed for leaching) at smaller size fractions, using a larger size fraction will underestimate leaching. The effect of particle size on leachate composition depends on the distribution and liberation of acid-generating or neutralizing minerals in the particles. White et al. (1999) found that reducing particle size overestimated the neutralization potential, and Scharer et al. (2000) noted that if particles are $>6.4 \mathrm{~mm}$, the availability of neutralization potential can be mass-transfer limited. If neutralizing or acid-generating minerals are of larger particle size in the field than in the leach tests, crushing can overestimate the acid-generating or neutralizing potential for those minerals in laboratory tests (Maest and Kuipers, 2005). Lapakko et al. (2006) determined sulfide dissolution rates in wastes using different particle sizes and found that leachate $\mathrm{pH}$ could increase or decrease with particle size depending on how size reduction affected the relative amounts of acid-generating or -neutralizing mineral surface area.

The PolyMet HCTs used an initial rinse (week 0) of $750 \mathrm{~mL}$ rather than the 500 or $1000 \mathrm{~mL}$ leach volumes described in the ASTM (2013) method. Subsequent rinse volumes were $500 \mathrm{~mL}$. The larger initial rinse volume would dilute solutes dissolved from secondary salts and minimize concentrations during those weeks. 


\subsection{Parameter trends in HCTs over time and charge/conductivity imbalances}

Rock samples used in HCTs should be weathered prior to conducting the tests if one of the goals is to examine the release of dissolved salts from mined materials (Maest and Kuipers, 2005). Typical $\mathrm{HCT} \mathrm{SO}$ trends in weathered samples subjected to a regular leaching sequence show initially elevated $\mathrm{SO}_{4}$ concentrations (early flush), rapidly decreasing concentrations, later increases in $\mathrm{SO}_{4}$ concentrations, and then a leveling off of concentrations, as shown in Figure 1. In samples that produce acidic drainage, $\mathrm{pH}$ values typically start in the neutral range and drop

to values below approximately 6 , when $\mathrm{Fe}$ and $\mathrm{SO}_{4}$ concentrations increase. Redox potentials, if available, often increase as soluble $\mathrm{Fe}$ and low pH values create enough $\mathrm{Fe}(\mathrm{II})$ and $\mathrm{Fe}(\mathrm{III})$ to be electroactive with respect to redox electrodes (lower $\mathrm{pH}$ values allow for increasing dissolved concentrations of Fe(III), causing the increase in ORP (see Figure 1)). As shown in Figure 1, Ca concentrations often account for the majority of the cation load during the early flush in the samples examined in this study. Other metals associated with the dissolution of sulfate minerals from sulfide deposits can also include $\mathrm{Ba}, \mathrm{Sr}, \mathrm{Fe}, \mathrm{Al}, \mathrm{Mg}$, and $\mathrm{K}$ (Price, 2009) and $\mathrm{Cu}$, $\mathrm{Mn}, \mathrm{Ni}, \mathrm{Pb}$, and $\mathrm{Zn}$ (Jambor et al., 2000). These and other metals can be elevated in the early ion release in HCTs. The HCT results presented in environmental impact statements or other documents used for mine permitting typically plot one constituent per graph in $\mathrm{mg} \mathrm{L}^{-1}$. Plotting major cations and anions in molar units and $\mathrm{pH}$ on a single graph helps reveal dissolution behavior throughout the test and the composition of soluble salts. 


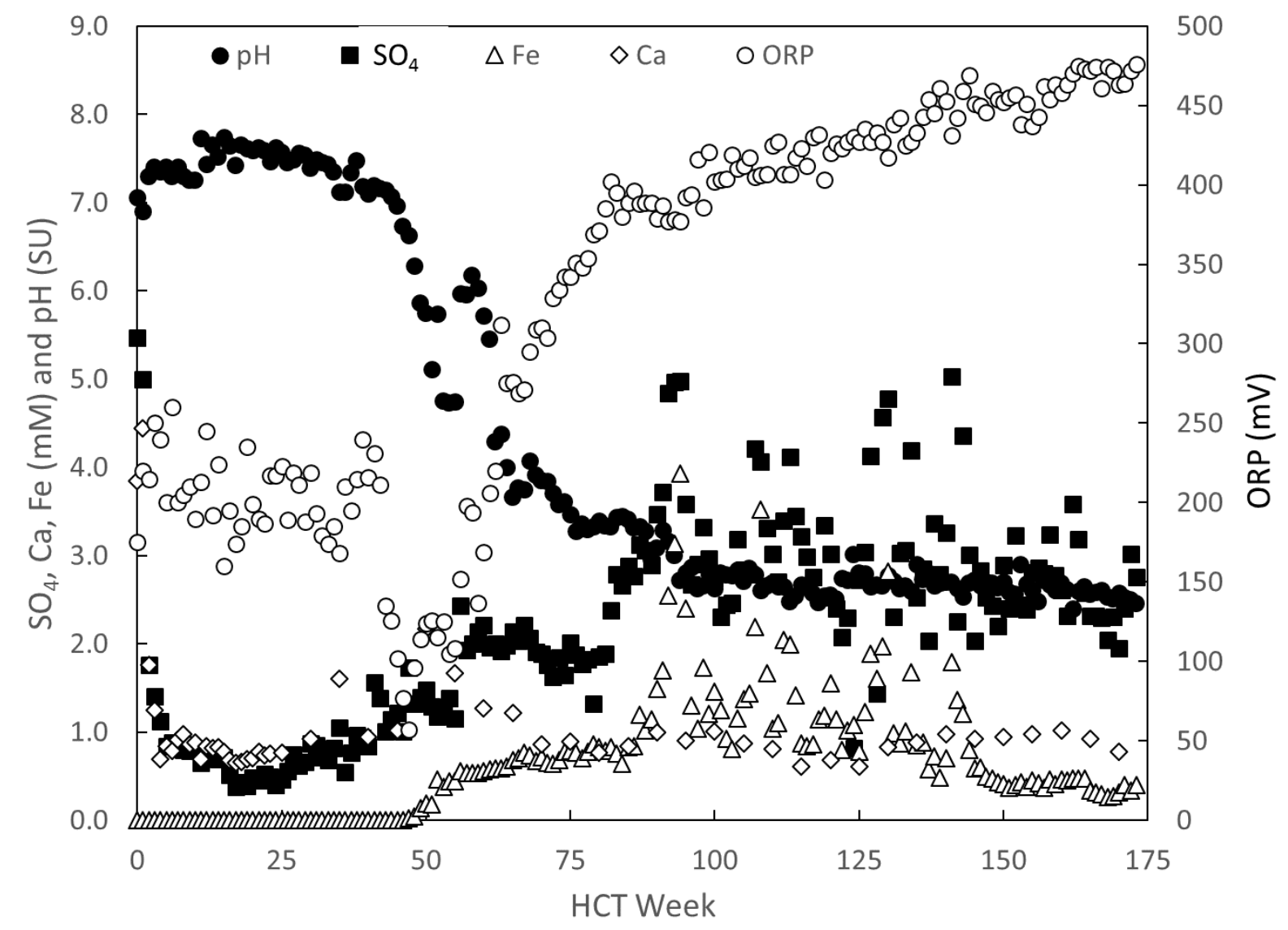

Figure 1. Typical parameter trends in a humidity cell test. Buckhorn Mine, HC-8. Gold Bowl garnet skarn.

\section{Charge and conductivity imbalances}

The meaningful use of speciation codes requires water analyses with quality data, and using the charge balance is a one way to evaluate the reliability of the water analyses. The ASTM (2013) method does recommend calculating charge balances for each HCT leachate sample. Selected HCT results were run in WATEQ4F (Ball and Nordstrom, 1991), and the charge balances were reviewed. If the $\mathrm{Cl}$ is $> \pm 25 \%$ in WATEQ $4 \mathrm{~F}$, the laboratory analytical results are in question. However, the $\mathrm{Cl}$ alone cannot indicate whether the cations or anions sums are incorrect. Using an approach proposed by McCleskey et al. (2011), the $\mathrm{Cl}$, using WATEQ4F modeling results, and 
the $\delta \mathrm{K}_{25}$, also calculated by WATEQ4F, can be used to determine whether cation or anion concentrations should be adjusted (McCleskey et al., 2012a and b).

As shown in Table 2 , the $\mathrm{Cl}$ and the $\delta \mathrm{K}_{25}$ exceeded $\pm 25 \%$ for three $\mathrm{HCT}$ samples, Pebble 025 0617-0637, week 0; Buckhorn HC-8, week 95; and Polymet 26027(616-626), week 198. These three samples should have been re-run, and they were rejected for our evaluation of salt dissolution and inverse modeling (Section 4.4). The McCleskey et al. (2011) approach was used to estimate whether cations or anions were too high/low, and the results are shown in Table 2 .

For WATEQ4F, a $\mathrm{Cl}$ of $\pm 25 \%$ ( $\pm 10 \%$ for other codes) is acceptable (see Eqn. 1 ), although a good laboratory should be able to achieve $\pm 10 \%$. All other samples had acceptable $\mathrm{Cl}$ values using WATEQ4F, and no other modifications were made to improve $\mathrm{Cl}$ values. The $\delta \mathrm{K}_{25}$ should also be within approximately \pm 20 to $25 \%$. However, a number of the samples in Table 2 had cation concentrations that were too high, suggesting that the measured conductivity values were in error. The results indicate that analytical measurements for HCT leachate samples should be evaluated more carefully and be re-run in the laboratory if the results are outside of acceptable $\mathrm{Cl}$ values. In addition, more care should be taken with conductivity measurements at the time of leachate collection. If standard quality assurance/quality control (QA/QC) measures are not followed (see, for example, U.S. E.P.A., 2002), the HCT measurements can only be considered qualitative at best, but modifications can be made to improve their reliability. 
Table 2. Speciated charge imbalance $(\mathrm{Cl})$ and conductivity imbalance $\left(\delta \mathrm{K}_{25}\right)$ results from WATEQ4F and adjustments for selected humidity cell test results

\begin{tabular}{|c|c|c|c|c|c|c|c|}
\hline Site & Sample & Week & $\begin{array}{c}\delta K_{25} \\
(\% \\
\text { diff) } \\
\end{array}$ & $\mathrm{Cl}$ (\% diff) & $\begin{array}{l}\text { Major Cations; } \\
\text { Anions } \\
\text { (measured) }^{\text {a }}\end{array}$ & $\begin{array}{l}\text { McCleskey et al. } \\
\text { (2011) } \\
\text { Result }\end{array}$ & $\begin{array}{l}\text { Revised } \\
\text { Result: } \mathrm{Cl} \\
\text { (\% diff) }\end{array}$ \\
\hline Pebble & $\begin{array}{c}\text { 025-0617- } \\
0637\end{array}$ & 0 & 85.9 & 35.4 & $\begin{array}{c}\mathrm{Mg}, \mathrm{Ca}, \mathrm{Na} \\
\mathrm{Mn}, \mathrm{Cu}, \mathrm{Al} ; \mathrm{SO}_{4}\end{array}$ & $\begin{array}{l}\text { Cations too high; } \\
\mathrm{Cl} \text { and } \delta \mathrm{K}_{25} \text { too } \\
\text { high likely decimal- } \\
\text { point error in }[\mathrm{Cu}] \\
\text { input }\end{array}$ & $\begin{array}{c}-9.7 \\
\text { Rejected }\end{array}$ \\
\hline Pebble & $\begin{array}{c}3069-0927- \\
0947\end{array}$ & 0 & 22.3 & 6.3 & $\mathrm{Ca} / \mathrm{Mg}, \mathrm{Cu} ; \mathrm{SO}_{4}$ & Cations too high & NA \\
\hline Pebble & $\begin{array}{c}3069-0927- \\
0947\end{array}$ & 143 & 5.7 & -4.7 & $\mathrm{Fe} ; \mathrm{SO}_{4}$ & $\begin{array}{l}\text { Within acceptable } \\
\text { limits for } \mathrm{Cl} \text { and } \\
\delta \mathrm{K}_{25}\end{array}$ & NA \\
\hline Buckhorn & $\mathrm{HC}-1$ & 1 & 48.6 & 7.2 & $\mathrm{Ca} ; \mathrm{SO}_{4}$ & Cations too high & NA \\
\hline Buckhorn & $\mathrm{HC}-1$ & 45 & 33.8 & 3.9 & $\mathrm{Fe}, \mathrm{Ca} ; \mathrm{SO}_{4}$ & Cations too high & NA \\
\hline Buckhorn & $\mathrm{HC}-8$ & 0 & 59.7 & -14.9 & $\mathrm{Ca} ; \mathrm{SO}_{4}$ & Anions too high & NA \\
\hline Buckhorn & $\mathrm{HC}-8$ & 95 & 25.9 & 38 & $\mathrm{Fe} ; \mathrm{SO}_{4}$ & $\begin{array}{c}\text { Cations too high; } \\
\mathrm{Cl} \text { and } \delta \mathrm{K}_{25} \text { too } \\
\text { high }\end{array}$ & $\begin{array}{c}17.1 \\
\text { Rejected }\end{array}$ \\
\hline PolyMet & $\begin{array}{c}337 C(510- \\
520)\end{array}$ & 10 & -22.2 & 8.6 & $\mathrm{Fe} ; \mathrm{SO}_{4}$ & $\begin{array}{l}\text { Within acceptable } \\
\text { limits for } \mathrm{Cl} \text { and } \\
\delta \mathrm{K}_{25}\end{array}$ & NA \\
\hline PolyMet & $\begin{array}{c}337 C(510- \\
520)\end{array}$ & 100 & 29.3 & -20 & $\mathrm{Fe} ; \mathrm{SO}^{\mathrm{b}}$ & Anions too high & NA \\
\hline PolyMet & $\begin{array}{c}367-(400- \\
405)\end{array}$ & 2 & -1.5 & 17.5 & $\begin{array}{c}\mathrm{Na}, \mathrm{Ca}, \mathrm{K} ; \mathrm{SO}_{4} \\
\mathrm{HCO}_{3}{ }^{\mathrm{b}}\end{array}$ & $\begin{array}{l}\text { Within acceptable } \\
\text { limits for } \mathrm{Cl} \text { and } \\
\qquad \mathrm{K}_{25}\end{array}$ & NA \\
\hline PolyMet & $\begin{array}{c}367-(400- \\
405)\end{array}$ & 186 & 19.4 & 16.3 & $\begin{array}{c}\mathrm{Ca}, \mathrm{Mg}, \mathrm{Fe} ; \\
\mathrm{SO}_{4}{ }^{\mathrm{b}}\end{array}$ & $\begin{array}{l}\text { Within acceptable } \\
\text { limits for } \mathrm{Cl} \text { and } \\
\qquad \delta \mathrm{K}_{25}\end{array}$ & NA \\
\hline PolyMet & $\begin{array}{c}26027(616- \\
626)\end{array}$ & 2 & 0.3 & 20.9 & $\begin{array}{l}\mathrm{Na}, \mathrm{Ca}, \mathrm{K}, \mathrm{Mg} ; \\
\mathrm{SO}_{4}, \mathrm{Cl}, \mathrm{HCO}_{3}{ }^{\mathrm{b}}\end{array}$ & $\begin{array}{l}\text { Within acceptable } \\
\text { limits for } \mathrm{Cl} \text { and } \\
\qquad \mathrm{K}_{25}\end{array}$ & NA \\
\hline PolyMet & $\begin{array}{c}26027(616- \\
626)\end{array}$ & 198 & 45.4 & -26.3 & $\begin{array}{l}\mathrm{Mg}, \mathrm{Fe}, \mathrm{Ca} ; \\
\mathrm{SO}_{4}{ }^{\mathrm{b}}\end{array}$ & $\begin{array}{l}\text { Anions too high; } \mathrm{Cl} \\
\text { and } \delta \mathrm{K}_{25} \text { too high }\end{array}$ & $\begin{array}{c}\text { NA } \\
\text { Rejected }\end{array}$ \\
\hline
\end{tabular}




\subsection{Oxidation-reduction reactions and rates}

\subsubsection{Iron speciation, Eh, and ferrihydrite saturation}

The ORP is rarely measured in $\mathrm{HCT}$ leachate, and the laboratory determination of Fe(II) and $\mathrm{Fe}(\mathrm{III})$ species is even more unusual. These determinations are very important when it comes to interpreting reactions involving Fe sulfide oxidation because the Fe(III) concentrations increase the oxidation rate and because of the precipitation of hydrated ferric oxide, which adsorbs trace metals and decreases the $\mathrm{pH}$. The Fe(II)/(III) concentrations should always be measured in acidic samples in which Fe is an important component, if you want to apply geochemical modeling and understand the reactions. Iron sulfide mineral oxidation produces waters with a wide range of $\mathrm{Fe}(\mathrm{II} / \mathrm{III})$ concentrations and $\mathrm{pH}$ values, and these must be measured for quality assurance/control purposes (charge balance). Moreover, interpretation of mineral dissolution and precipitation reactions, sorption reactions for trace elements, interpretation of $\mathrm{pH}$ changes, and interpretation of aquifer permeability changes require determination of $\mathrm{Fe}(\mathrm{II} / \mathrm{III})$ concentrations. The results presented in this section indicate that ORP or Eh measurements, which are recommended by the ASTM (2013) method, are not useful at pH values above approximately 4 (and probably not more than qualitative from $\mathrm{pH} 3$ to 4 ), unless the Fe species are measured directly.

Figure 2a shows the changes in Fe speciation, dissolved $\mathrm{Cu}$ concentrations, $\mathrm{pH}$, Eh, and ferrihydrite SI over the course of the test for the Pebble sample. Sulfate concentrations are shown for the period when $\mathrm{Fe}$ and $\mathrm{SO}_{4}$ concentrations were increasing most rapidly. When the $\mathrm{pH}$ dropped below 4, ferrihydrite was consistently undersaturated (week 64). The Eh values do 
not become meaningful until $\mathrm{pH}$ values drop below about 4 , which allows for increased concentrations of $\mathrm{Fe}(\mathrm{III})$ and measurable values of both Fe(II) and Fe(III) (Nordstrom, 2011). The Pebble HCTs were the only samples examined that used trickle leach (see Table 1) and that had $\mathrm{Fe}(\mathrm{III})$ in excess of $\mathrm{Fe}$ (II) concentrations. The $\mathrm{Fe}$ (III) concentrations and $\mathrm{pH}$ were generally inversely correlated, and when $\mathrm{pH}$ values dropped below 3 for the first time (week 115), $\mathrm{Fe}(\mathrm{III})$ concentrations rose in response to the dissolution of Fe sulfide. We describe this as Fe sulfide oxidation and dissolution because $\mathrm{SO}_{4}$ and Fe concentrations rose concurrently, the $\mathrm{pH}$ is below 3 (Figure 2a), and Fe sulfide dissolution rates are faster than those for silicates or oxides (e.g. King and McSween, 2005). Aluminum and silica concentrations remained low, and Fe silicate or carbonate minerals were not identified above trace levels in the sample. Hence, the data argue against the observed Fe increases being related to dissolution of rock-forming or carbonate minerals. The Fe(II) concentrations remained low as the Eh rose and Fe(II) was converted to $\mathrm{Fe}(\mathrm{III})$. Early in the test, WATEQ4F output showed that the most common Fe(II) species were $\mathrm{Fe}^{2+}$ and $\mathrm{FeSO}_{4}{ }^{0}$, and the most common ferric species were $\mathrm{Fe}(\mathrm{OH})_{2}{ }^{+}, \mathrm{FeSO}_{4}{ }^{+}$, and $\mathrm{FeOH}_{2}{ }^{+}$. With the rise in $\mathrm{Fe}(\mathrm{III})$ concentrations (weeks 115 and 139) and throughout the remainder of the test, $\mathrm{FeSO}_{4}{ }^{+}$dominated the Fe speciation. Copper concentrations were higher than Fe initially, especially in the early-flush sample (approximately $1200 \mu \mathrm{M}$ ). Copper values peaked at week 123, but Fe concentrations continued to climb to week 139. Chalcopyrite or bornite could be dissolving early in the tests. The $\mathrm{Cl}$ values were within acceptable limits for $90 \%$ of the leachate samples. Measuring Eh in HCT samples with $\mathrm{pH}$ values below 4 can improve charge balances and the interpretation of Fe behavior, including sulfide oxidation, in HCTs. Charge balances are 
improved in such samples because knowledge of the oxidation state of Fe allows for improvements in calculating the concentration of aqueous species with different charges.

Results for the Buckhorn and PolyMet samples are shown in Figures $2 \mathrm{~b}$ and $\mathrm{c}$. Both HCT samples were run using the flood leach approach, and the Fe species appear to be responding to this difference in experimental technique. Ferrous Fe dominates in the two flood-leached samples, whereas ferric Fe dominates in the Pebble sample. For the Buckhorn sample (HC-1), ferrihydrite was consistently oversaturated earlier in the test (until week 35). The drop in SI after this point was accompanied by a drop from near neutral (6.45) to more acidic (5.11) pH values. Iron concentrations were low until week 30. Between weeks 1 and 20, Fe(III) species dominated, 


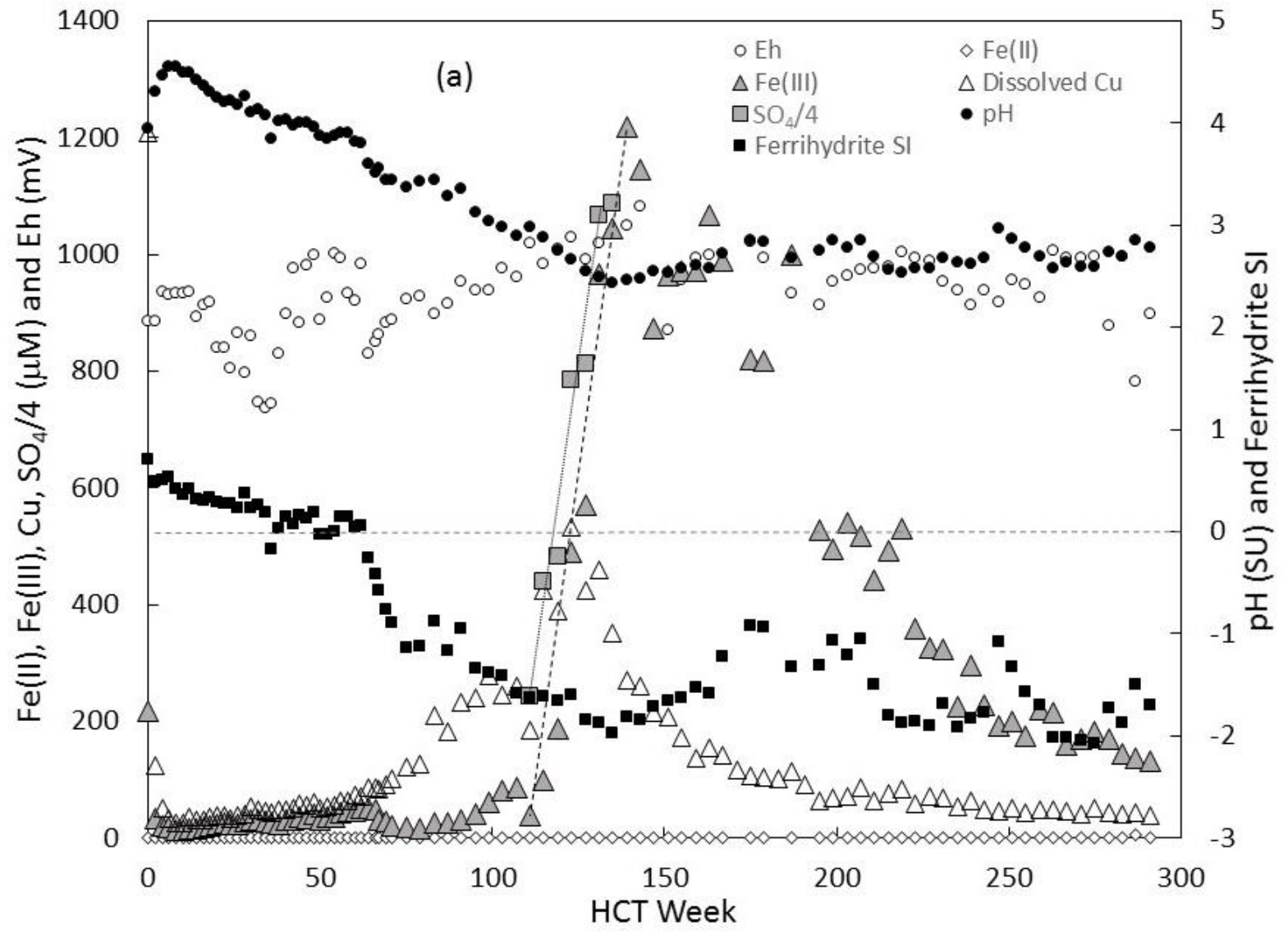




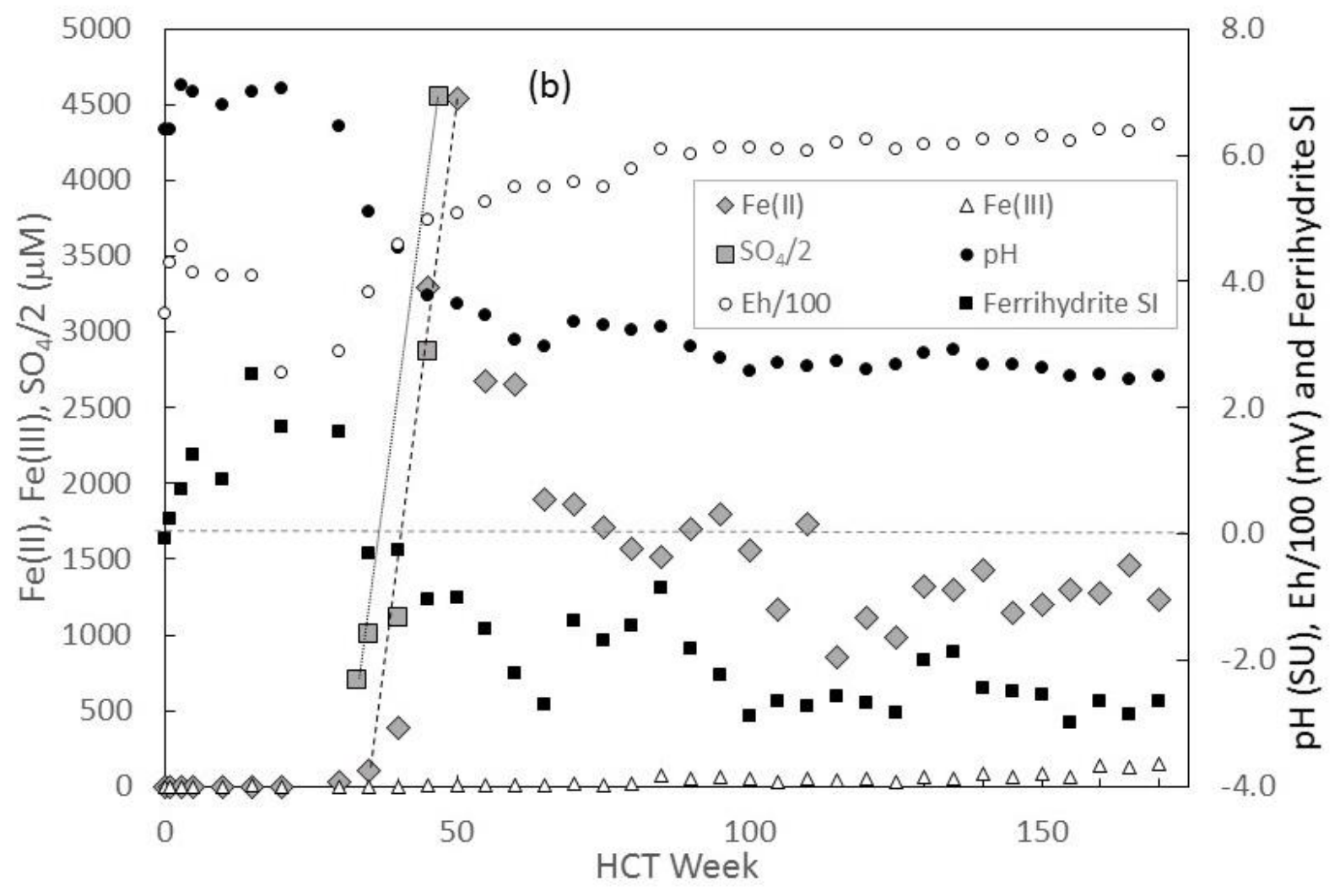




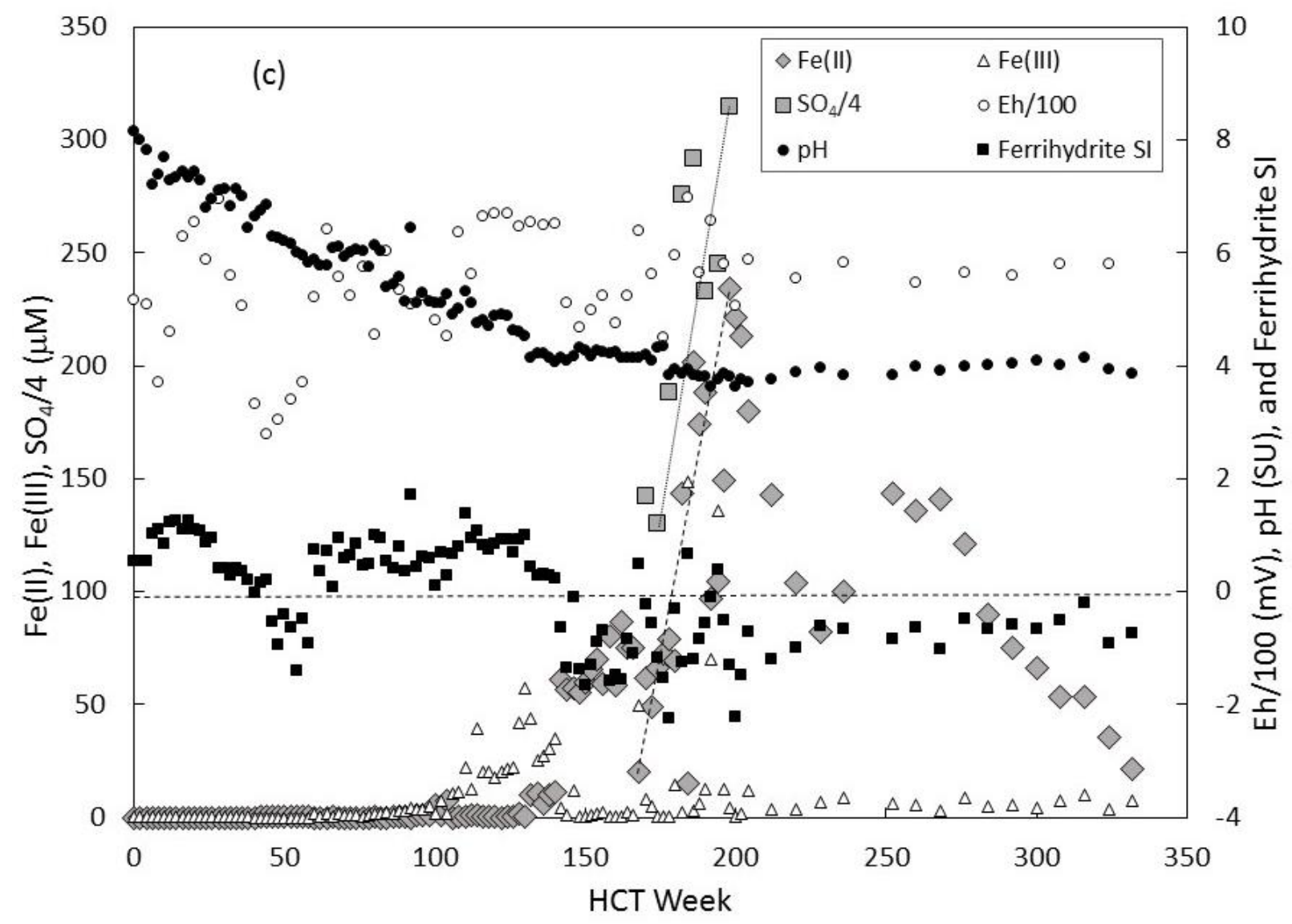

Figure 2. Dissolved Fe species, ferrihydrite saturation index (SI), $\mathrm{SO}_{4}$ (only during rapid increase), and Eh for (a) Pebble sample 3069-0927-0947, with dissolved Cu, (b) Buckhorn Mine sample HC-1, and (c) PolyMet Project sample 26027(616-626). Horizontal dashed line is $\mathrm{SI}=0$, and the slanted vertical dashed lines represent the part of the curve used to calculate Fe sulfide dissolution rates.

especially $\mathrm{Fe}(\mathrm{OH})_{2}{ }^{1+}$ and $\mathrm{Fe}(\mathrm{OH})_{3}{ }^{0}$. Concentrations of $\mathrm{Fe}(\mathrm{II})$ began to rise after approximately week 20, as did $\mathrm{SO}_{4}$ concentrations, and peaked at week 50. Unlike the Pebble sample, $\mathrm{Fe}(\mathrm{II})$ values accounted for at least $90 \%$ of the total Fe from week 30 to the end of the test. Ferrous Fe species were predominantly $\mathrm{Fe}^{2+}$ (approximately $80 \%$ ) and $\mathrm{FeSO}_{4}{ }^{0}$ (approximately $15 \%$ ). From week 90 to the end of the test, $\mathrm{pH}$ values were buffered between 2.5 and 3.0. 
The PolyMet sample (Figure 2c) had the slowest approach to acidic conditions of the three HCT samples. The sample took 90 weeks to drop from $\mathrm{pH} 8$ to $\mathrm{pH} 5$, and $\mathrm{pH}$ values were not consistently below 4 until week 178. The Eh values were somewhat erratic throughout the test, as were Fe concentrations. Modeled concentrations of Fe(III) began to increase when pH values dropped to approximately 5 (about week 100). From week 130 to week 150, when pH values dropped to approximately 4, Fe(III) concentrations decreased as Fe(II) concentrations rose and remained dominant for the remainder of the test. The use of the flood leach method, as in the Buckhorn sample, likely suppressed oxidation to ferric Fe. When $\mathrm{pH}$ values dropped to approximately 4 (about week 140), ferrihydrite was more consistently undersaturated. Ferrous Fe and $\mathrm{SO}_{4}$ concentrations peaked in week 198, and $\mathrm{pH}$ and Eh values were more stable after this point.

For all three samples, Fe concentrations quickly dropped after they peaked, suggesting that Fe oxyhydroxides could be at least partially coating the available sulfide minerals and limiting further dissolution. The ferrihydrite SI values in the PolyMet sample were closest to saturation after Fe concentrations peaked, and iron coatings were noted on certain sulfides in PolyMet (Babbitt) waste rock piles (see Section 4.6.2; Lapakko et al., 2004).

\subsubsection{Metal sulfide oxidation and sulfate mineral dissolution rates}

The aqueous components of metal-sulfide oxidation can be tracked to help distinguish metal sulfide and metal sulfate salt dissolution. The rate of generation of dissolved metals and $\mathrm{SO}_{4}$ can also help distinguish sulfide oxidation from sulfate salt dissolution. Sulfide oxidation rates are often expressed in terms of the available sulfide surface area. However, surface areas 
measurements were not made for the selected HCTs and are very difficult to estimate for HCTs. Although the ASTM (2013) method recommends measuring surface areas of acid-generating and acid-neutralizing minerals and some practitioners do estimate surface area in HCTs, it is not commonly done (Banwart et al., 2002; Lapakko and Antonson, 2006; Lapakko and Trujillo, 2015). Dissolution of many metal sulfate salts is so rapid that few experiments have bothered to measure rates. Short-term leach tests designed to evaluate the production of metals and other constituents from mine wastes (e.g., synthetic precipitation leaching procedure, meteoric water mobility procedure) rely on the rapid dissolution of metal sulfide weathering products.

\subsubsection{Sulfide stoichiometry, oxidation and release rates, and scaling factors}

\subsubsection{Sulfide stoichiometry}

The Fe:S ratio in the most common metal sulfides in mine wastes, pyrite or marcasite and chalcopyrite, is 1:2 ( $\mathrm{FeS}_{2}$ and $\left.\mathrm{CuFeS}_{2}\right)$. The ratio in pyrrhotite, which is the most likely Fe sulfide in the Buckhorn and PolyMet samples, is close to 1:1, depending on the value of $\mathrm{x}$ in the mineral formula $\left(\mathrm{Fe}_{(1-\mathrm{x})} \mathrm{S}\right.$; Lapakko et al., 2004). For the Buckhorn Mine sample (HC-1, garnet skarn), the Fe:S molar ratio in solution varies between 0.5 and close to 1 , suggesting that pyrite or pyrrhotite are the dissolving phases between weeks 40 and 50 when Fe concentrations increased most rapidly. For the Pebble granodiorite sample (3069-0927-0947), mineralogic analysis of the sample after leach testing showed that pyrite was the dominant sulfide ( $2 \%$ in thin section) and occurred disseminated, in thin veins, and as occasional aggregates. Traces of chalcopyrite and bornite were found in pyrite grains, some of which were covered with a fine orange-red or orange-brown precipitate (PLP, 2011a). However, the most likely dissolving phase is pyrite, and a lower Fe:S ratio in solution infers that Fe is being lost from solution in the Pebble 
$\mathrm{HCT}$. Therefore, $\mathrm{SO}_{4}$ will likely be a better constituent to use for oxidation rates than Fe. Gypsum does not appear to affect this result, as subtracting $\mathrm{Ca}$ from $\mathrm{SO}_{4}$ did not change the trend. If gypsum dissolution were affecting solute concentrations, Ca molar concentrations would be higher than they are, and subtracting them from $\mathrm{SO}_{4}$ molar concentrations would change the Fe:S ratios.

Figure 3 shows the Fe and S molar concentrations for all weeks for two of the three samples discussed above, Pebble and Buckhorn, and the effect of $\mathrm{pH}$ and the reacting sulfides on water chemistry. The results are broken into two $\mathrm{pH}$ ranges: $\leq 4$ and $>4$. The PolyMet sample had few leachate samples with $\mathrm{pH}$ values $\leq 4$, and the results are not shown on Figure 3 . The dotted lines in the diagram refer to three different Fe:S molar ratios. The 1:1 ratio represents the maximum ratio for troilite (FeS) as a surrogate for pyrrhotite of unknown specific composition; the 1:2 represents pyrite $\left(\mathrm{FeS}_{2}\right)$ and chalcopyrite $\left(\mathrm{CuFeS}_{2}\right)$, and the 1:4 ratio represents bornite $\left(\mathrm{Cu}_{5} \mathrm{FeS}_{4}\right)$. Results for the samples with $\mathrm{pH}$ values $\leq 4$ had higher Fe:S ratios and higher Fe and $\mathrm{S}$ concentrations than those with higher $\mathrm{pH}$ values. For samples with $\mathrm{pH}$ values higher than 4, most of the Fe will precipitate as an insoluble hydrous ferric oxide. The solubility of the precipitate increases substantially at $\mathrm{pH}$ values less than 4, but as shown in Figure 2, dissolved Fe concentrations increased rapidly then slowly decreased, whereas the $\mathrm{pH}$ remained constant. Hence, the Fe must be dissolving from a rapidly soluble mineral and then reaching supersaturation with respect to an Fe(III) precipitate, which then began precipitating and aging to a more stable, less soluble, form. Among other reasons, as noted in Section 4.3.1, the only anion that consistently increased rapidly in concentration with the $\mathrm{Fe}$ is $\mathrm{SO}_{4}$, and we infer that pyrite or pyrrhotite was oxidizing. 
The Fe:S ratios for the lower-pH Pebble samples were closest to the 1:4 line, especially for the samples with higher $\mathrm{Fe}$ and $\mathrm{SO}_{4}$ concentrations. Bornite was identified as a minor constituent in the Pebble HCT sample, but because of the likely precipitation of Fe oxyhydroxides as coatings, the solution chemistry alone cannot be used to help identify the stoichiometry of the dissolving Fe sulfide phases. In such instances, additional mineralogical data would be needed to complete the mass balances and interpret the stoichiometries. The lower-pH Buckhorn samples had the highest Fe:S ratios, with most values between 1:2 and 1:1. Pyrrhotite, with a near 1:1 Fe:S ratio, was the most likely dissolving sulfide phase in this sample, which had the highest oxidation rate, as expected because of the higher reactivity of pyrrhotite (Nicholson and Scharer, 1994), the higher sulfide content, and the low neutralization potential (see Table 1). 




Figure 3. Fe and sulfate concentrations compared to constant Fe:S molar ratios for pyrrhotite (near 1:1), pyrite (1:2) and bornite (1:4) stoichiometry, for Pebble sample 3069-0927-0947 and the Buckhorn sample HC-1. HCT leachate samples are divided into those with $\mathrm{pH}$ values $\leq 4.0$ and $>4.0$.

\subsubsection{Sulfide oxidation and release rates}

The aqueous components of metal sulfide oxidation can be tracked to help distinguish metal sulfide and metal sulfate salt dissolution. The rate of generation of dissolved metals and $\mathrm{SO}_{4}$ can also help distinguish sulfide oxidation from sulfate salt dissolution. Dissolution of many metal sulfate salts is so rapid that few experiments have bothered to measure rates. Short-term leach tests designed to evaluate the production of metals and other constituents from mine wastes 
(e.g., synthetic precipitation leaching procedure, meteoric water mobility procedure) rely on the rapid dissolution of metal sulfide weathering products.

Depending on where in the HCT results the reaction or release rates are derived, the time to acid production and other variables can vary widely. A comparison of $\mathrm{SO}_{4}$ release rates during maximum sulfide oxidation and the end of testing is provided in Table 3 , in $\mathrm{mg} \mathrm{kg}^{-1} \mathrm{wk}^{-1}$, the units most commonly used in HCT evaluations. The dissolving sulfides were assumed to be pyrite for the Pebble sample, and pyrrhotite, with a 1:1 Fe:S ratio, for the Buckhorn and PolyMet samples. As shown in Table 3, when sulfides are oxidizing most rapidly (e.g., weeks 111 to 139 for the Pebble sample), the release rates are substantially higher than during steadystate conditions near the end of the tests. Maximum $\mathrm{SO}_{4}$ release rates were 2 to 3 times higher than steady-state rates. Sulfate release rates were even higher during early flush conditions, as shown in Table 3. Similar trends in $\mathrm{SO}_{4}$ release rates were seen in Lapakko and Trujillo (2015).

Conditions across tests were different in the three samples, but a general comparison is informative. In the Pebble sample, $\mathrm{SO}_{4}$ and ferric Fe concentrations increased most rapidly (see Figure 2a), and pyrite, possibly with minor chalcopyrite and bornite, was the most likely dissolving phase. The presence of multiple sulfide minerals will affect oxidation rates; sulfides containing $\mathrm{Cu}$ or $\mathrm{Zn}$ will oxidize more rapidly when in contact with pyrite, and pyrite will oxidize more slowly through galvanic protection (Nordstrom, 1982; Kwong et al., 2003; Chopard et al., 2015). The maximum sulfide oxidation rate for the Buckhorn sample was about 25 times faster than for the Pebble sample (see Table 3). In the Buckhorn and PolyMet samples (see Figures $2 \mathrm{~b}$ and $2 \mathrm{c}$ ), $\mathrm{SO}_{4}$ and ferrous $\mathrm{Fe}$ increased during rapid sulfide oxidation, and pyrrhotite was the 
most likely dissolving phase in both samples. Iron sulfide in the PolyMet sample took the longest time to oxidize, with concentrations of $\mathrm{Fe}$ and $\mathrm{SO}_{4}$ not increasing rapidly and consistently until week 184 . The maximum sulfide oxidation rate for the Buckhorn sample was about 6.5 times faster than for the PolyMet sample (Table 3).

The sample with the fastest sulfide oxidation rate, from the Buckhorn Mine, was not the one with the highest sulfide content. The Buckhorn sample had the highest total S content $(4.72 \%$ S), but the sulfide percentage was lower than that for the Pebble sample. The higher rate for the Buckhorn sample is attributed to the presence of faster-reacting pyrrhotite (Nicholson and Scharer, 1994), whereas pyrite is the dominant Fe sulfide mineral in the Pebble sample. However, within a given lithology in a given deposit, sulfide content could control how quickly sulfide oxidation occurs. The Buckhorn sample with the higher sulfide content (HC-1, 1.91\% sulfide S) produced acid more rapidly and showed rapid $\mathrm{Fe}$ and $\mathrm{SO}_{4}$ increases sooner than the sample with lower sulfide content (HC-8, 0.87\% sulfide S), as shown by comparing Figures 1 and $2 b$.

Literature values for maximum Fe sulfide oxidation rates in optimized laboratory batch experiments using only pyrite or only pyrrhotite, converted to $\mathrm{mg} \mathrm{kg}^{-1} \mathrm{wk}^{-1}$ (for the sample as a whole and for the amount of Fe sulfide), are provided in Table 4. Again, conditions in the singlemineral batch experiments are clearly different from each other and from those in the HCTs, but general comparisons are informative. The highest Fe sulfide oxidation rates are in experiments with Fe(III), the lowest rates are with added oxygen, and the microbial rates are intermediate, as shown in Table 4. Sulfide oxidation rates are higher under acidic conditions 
because low $\mathrm{pH}$ increases the concentration of aqueous $\mathrm{Fe}(\mathrm{III})$, and the oxidation rate is a direct function of Fe(III) concentration (Nordstrom and Alpers, 1999). The similar measured rates for pyrite oxidation by oxygen shown in Table 4 for Nicholson et al. (1988; neutral pH) and McKibben and Barnes (1986; low pH) can be attributed to differences in grain size, type of pyrite used, sample preparation, and experimental setup (stir rate, method of introducing oxygen, etc.).

In general, laboratory rates for the single-sulfide mineral experiments are faster than those in the HCTs examined, as expected. However, the maximum Fe sulfide oxidation rate for the Buckhorn sample, in which pyrrhotite is the likely dissolving phase, is similar to that found for pyrrhotite by Nicholson and Sharer (1994). The overall range for microbial pyrite oxidation at $\mathrm{pH} 2$ for batch laboratory experiments was about 210,000 to $360,000 \mathrm{mg}_{\mathrm{sO}_{4}} \mathrm{~kg}_{\text {prite }}{ }^{-1}$ week $^{-1}$. Sulfide oxidation rates in HCTs would be expected to be slower than those in optimized batch laboratory experiments because there is less opportunity in the HCTs for Fe-oxidizing bacteria to colonize (regular rinsing, no nutrients added, no inocula added), $\mathrm{pH}$ values are higher so that the Fe(III) concentrations are lower, and exposed surface areas are not known. Nevertheless, the maximum sulfide oxidation rate for the Buckhorn sample comes within about one order of magnitude of the batch microbially mediated pyrite oxidation rate (see Tables 3 and 4), which suggests that Fe-oxidizers could have colonized the sample. Abiotic pyrrhotite oxidation rates by oxygen were clearly faster than those for pyrite, but no microbial rates for pyrrhotite are known. Without the bacteria, the oxidation rate would depend on the rate of abiotic oxidation of aqueous Fe(II) by oxygen, which would be substantially slower (see Table 4; e.g., 1,300 $\mathrm{mg}_{\mathrm{SO}_{4}}$ $\mathrm{kg}_{\mathrm{Fe} \text { sulfide }}{ }^{-1}$ week ${ }^{-1}$ for the McKibben and Barnes (1986) experiments). If the $\mathrm{pH}$ values in the 
beginning of the tests are circumneutral, such as the PolyMet and Buckhorn examples, the pyrite cannot oxidize sufficiently to compare with these rates. Although this is indirect evidence, it does suggest that sulfide mineral oxidation rates are strongly dependent on the presence of Fe-oxidizing bacteria, which are not monitored in HCTs. Because of the lack of information on microbial activity in the HCTs, one should look for these rapid increases in Fe and $\mathrm{SO}_{4}$ concentrations that indicate pyrite or pyrrhotite oxidation and assume that would be a worse-case scenario for application of laboratory rates to field conditions. Modeling of Duluth Complex waste rock by Seal et al. (2015), using literature values for pyrrhotite oxidation, predicted that the sulfide would be depleted in two years; modeling using laboratory rates from Duluth rocks predicted only $20 \%$ pyrrhotite depletion, which matched well with field observations.

Table 3. Sulfate release rates and conditions during early flush, maximum Fe sulfide oxidation, and "steady-state" conditions ${ }^{1}$ for the Pebble, Buckhorn, and PolyMet project HCTs $^{2}$

\begin{tabular}{|c|c|c|c|c|}
\hline $\begin{array}{c}\text { Mine or Project, } \\
\text { Location (USA) }\end{array}$ & Units or Conditions & $\begin{array}{c}\text { Maximum } \\
\text { Early } \\
\text { Flush }\end{array}$ & $\begin{array}{c}\text { Maximum Fe } \\
\text { Sulfide Oxidation }\end{array}$ & $\begin{array}{c}\text { Mean Steady- } \\
\text { state }\end{array}$ \\
\hline Pebble Project, & $\mathrm{mg}_{\mathrm{SO}_{4}} \mathrm{~kg}_{\text {material }}{ }^{-1} \mathrm{wk}^{-1}$ & 513 & 206 & 68.7 \\
\hline Alaska; (3069-0927- & $\mathrm{mg}_{\mathrm{SO}_{4}} \mathrm{~kg}_{\text {pyrite }}{ }^{-1} \mathrm{wk}^{-1}$ & NA & 925 & 309 \\
\hline 0947); granodiorite; & HCT wks & 0 & 111-139 & $275-291$ \\
\hline $2.44 \% \mathrm{~S}$ & $\mathrm{pH}$ range & 3.95 & $2.44-2.59$ & $2.51-2.91$ \\
\hline Buckhorn Mine, & $\mathrm{mg}_{\mathrm{sO}_{4}} \mathrm{~kg}_{\text {material }}{ }^{-1} \mathrm{wk}^{-1}$ & 201 & 429 & 168 \\
\hline Washington; (HC-1 & $\mathrm{mg}_{\mathrm{SO}_{4}} \mathrm{~kg}_{\text {pyrrhotite }}{ }^{-1} \mathrm{wk}^{-1}$ & NA & 22,500 & 8,800 \\
\hline $\begin{array}{l}\text { GB-C13-419); } \\
\text { magnetite skarn; }\end{array}$ & HCT wks & 1 & $35-50$ & $169-173$ \\
\hline $1.91 \% \mathrm{~s}$ & $\mathrm{pH}$ range & 6.4 & $3.65-4.52$ & $2.42-2.49$ \\
\hline PolyMet Project, & $\mathrm{mg}_{\mathrm{sO}_{4}} \mathrm{~kg}_{\text {material }}{ }^{-1} \mathrm{wk}^{-1}$ & 32.0 & 62.9 & 36.3 \\
\hline Minnesota & $\mathrm{mg}_{\mathrm{SO}_{4}} \mathrm{~kg}_{\text {pyrrhotite }}{ }^{-1} \mathrm{wk}^{-1}$ & NA & 3,460 & 1,990 \\
\hline
\end{tabular}


$(26027(616-626))$

HCT wks

2

184-198

252-308

anorthositic

troctolite; $1.83 \% \mathrm{~S}$

$\mathrm{pH}$ range

8.01

3.63-3.93

3.86-4.15

1 last five weeks of $\mathrm{HCT}$ with $\mathrm{Fe}$ and $\mathrm{SO}_{4}$ data, or weeks with most stable release rates

2 using \% sulfide S values for Pebble and Buckhorn; assumed \% sulfide S = \% total S for PolyMet sample (\% sulfide S not available)

NA not applicable for early flush, which does not directly reflect Fe sulfide oxidation

Table 4. Literature values for maximum Fe sulfide oxidation rates in controlled experiments using single-sulfide samples, expressed as $\mathrm{SO}_{4}$ release rates

\begin{tabular}{|c|c|c|}
\hline Source and Notes & $\begin{array}{c}\text { Iron Sulfide } \\
\text { pH } \\
\text { Microbial/Abiotic }\end{array}$ & $\begin{array}{c}\text { Maximum Fe sulfide } \\
\text { oxidation rate } \\
\left(\mathrm{mg}_{\mathrm{so}_{4}} \mathrm{~kg}_{\text {Fe sulfide }}{ }^{-1} \text { week }^{-1}\right)\end{array}$ \\
\hline $\begin{array}{l}\text { Atkins, } 1978 \text { (used } 10 \% \\
\text { pulp density and varying } \\
\text { slopes) }\end{array}$ & $\begin{array}{c}\text { pyrite } \\
\text { pH } 2 \\
\text { microbial }\end{array}$ & $206,000-275,000$ \\
\hline $\begin{array}{l}\text { Olson, } 1991 \text { (inter- } \\
\text { laboratory comparison } \\
\text { using } 8 \text { labs) }\end{array}$ & $\begin{array}{c}\text { pyrite } \\
\mathrm{pH} 2 \text { (initial) } \\
\text { microbial }\end{array}$ & 358,000 \\
\hline $\begin{array}{l}\text { Rimstidt and Newcomb, } \\
1993\end{array}$ & $\begin{array}{c}\text { pyrite } \\
\text { pH } 2 \\
\text { abiotic by Fe(III) }\end{array}$ & 385,000 to $1,190,000$ \\
\hline $\begin{array}{l}\text { McKibben and Barnes, } \\
1986\end{array}$ & $\begin{array}{c}\text { pyrite } \\
\mathrm{pH} 1.89 \\
\text { abiotic by } \mathrm{O}_{2} \\
\end{array}$ & 1,300 \\
\hline $\begin{array}{l}\text { Nicholson et al., } 1988 \\
\text { (overall mean for } 6 \text { pyrite } \\
\text { types) }\end{array}$ & $\begin{array}{c}\text { pyrite } \\
\text { pH 7.6-8 } \\
\text { abiotic by } \mathrm{O}_{2}\end{array}$ & 2,270 \\
\hline $\begin{array}{l}\text { Nicholson and Scharer, } \\
1994\end{array}$ & $\begin{array}{c}\text { pyrrhotite } \\
\mathrm{pH} 2 \\
\text { abiotic by } \mathrm{O}_{2} \\
\end{array}$ & 32,000 \\
\hline $\begin{array}{l}\text { Janzen et al., } 2000 \\
\text { (based on Fe(II) release; } \\
\text { mean of } 12 \text { samples) }\end{array}$ & $\begin{array}{c}\text { pyrrhotite } \\
\mathrm{pH} 2.75 \\
\text { abiotic by } \mathrm{O}_{2}\end{array}$ & 421,000 \\
\hline
\end{tabular}

\subsubsection{3 "Steady-state" misconceptions}

A common conceptual model of the scaling of HCTs or other leach tests or field results and the areas over which kinetic or "steady state" conditions apply is shown in Figure 4. 


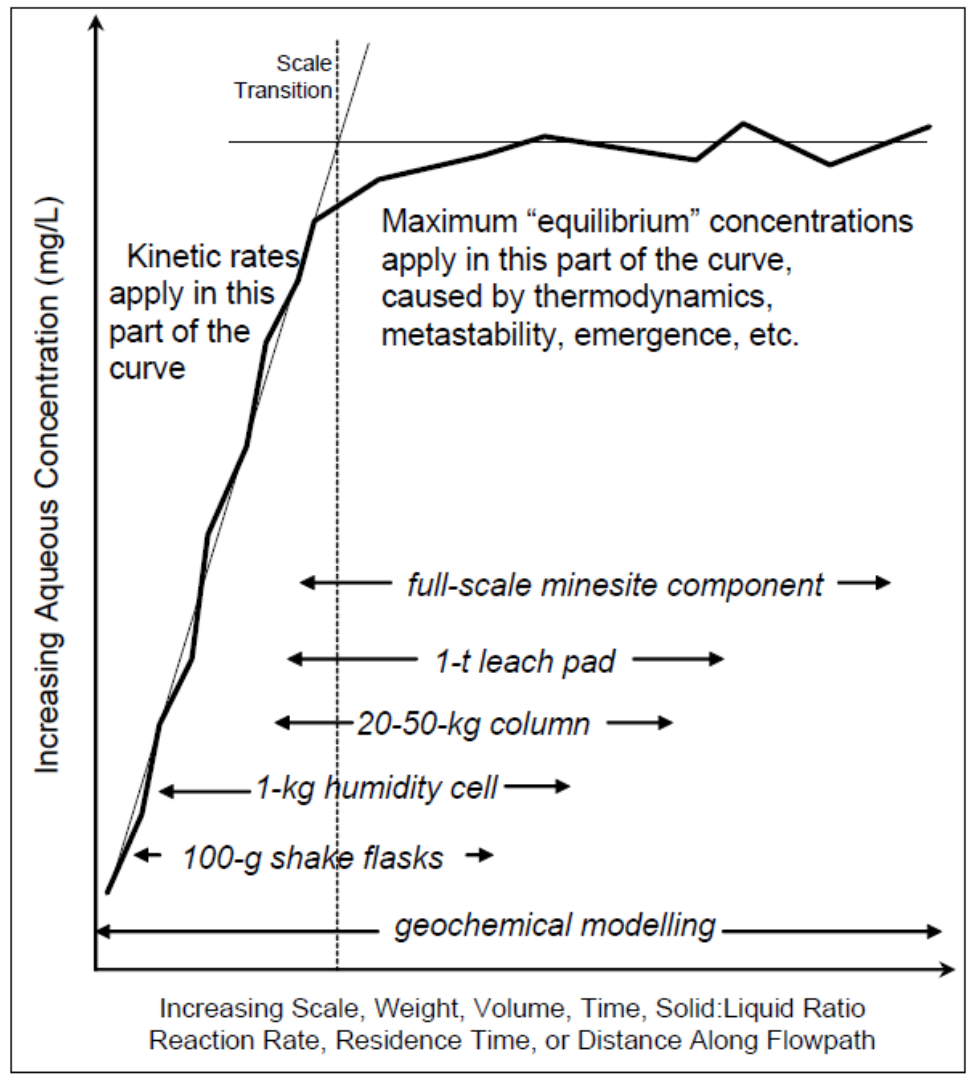

Figure 4. Conceptual model for scaling mine drainage chemistry and areas of the curve over which kinetic rates and steady-state concentrations apply, after Morin and Hutt, 2007.

One focus in HCT interpretation has been on the balance between the oxidation of acid-

producing sulfide minerals on the one hand and the dissolution of neutralizing minerals on the other. An assumption is made that equilibrium conditions are not reached until the end of the test when rates become "steady," or after a prolonged period in the field, and all earlier parts of the test reflect the kinetics of sulfide dissolution (Morin, 2013; Morin and Hutt, 2007). Consequently, practitioners believe that the only information that can be reliably derived from HCTs is reaction rates (rather than concentrations), and that rates reflecting long-term weathering must be derived from the end of the test. However, the ASTM (2013) method states that the test is not designed to produce effluents that are in chemical equilibrium 
with the solid phase sample. Furthermore, this conceptual model of Morin and Hutt (2007) seems to bear little resemblance to the actual time series data from an HCT. The conceptual model for HCTs seems quite unclear, especially regarding when to stop the test and over what time period the results should be averaged. As Lapakko and Wessels (1995) remind us, the notion of constant concentrations indicating completion of geochemical processes is erroneous and has been known for some time.

The use of "equilibrium" or "steady-state" for HCTs in mine site predictive modeling efforts is inappropriate for the following reasons. First, equilibrium is not the appropriate designation. Equilibrium is not a condition that can be reached in this type of open system (either field or lab). Second, the "pseudo steady-state" rates often miss major episodes of pyrite oxidation and salt dissolution that usually occur earlier in the tests and continuously or periodically in the field. Rates observed during portions of the HCT are really transient states reflecting the influence of transient hydraulics and transient sulfide oxidation along with gangue-mineral reaction rates. If one were to use steady-state rates to predict metal concentrations in streams, conditions that would produce the highest solute concentrations and have the highest potential to adversely affect water quality and aquatic biota would be ignored. Third, there is no commonly accepted procedure for applying HCT results to field situations, and it is not obvious that a single prescriptive approach would be adequate for the broad range of these sulfide mineral systems.

Our evaluation shows that sulfate salts dissolve early in testing, and that sulfides have their maximum oxidation for a relatively short period of time near the middle of a year-long (or longer) test. Hence, peaks and valleys occur during the test and the general increase to a 
plateau as shown by Morin and Hutt (2007) bears little resemblance to actual observations. As a conceptual model, Figure 4 is overly simplistic because it does not take into account numerous physical, chemical, biological, and hydrological factors that complicate the use of scaling in predictions. Actual HCT concentrations can decrease as well as increase with considerable variability over some length of time. They also tend to reach a constant concentration that is a minimal value or sometimes near the average but never a maximum value. Hence, Figure 4 is not only meaningless as a conceptual model, but it promotes a false impression of field conditions. In particular, metals, $\mathrm{SO}_{4}$, and acidity can be stored in pools, films, and efflorescent salts in underground mines and waste deposits and flushed occasionally by flowing water (see, e.g., Nordstrom and Alpers, 1999; Jamieson et al., 2005a, b; and Hammarstrom et al., 2005). These and other hydrogeochemical processes are not represented in HCTs (Smith et al., 2013c; Parbhakar-Fox and Lottermoser, 2015). We suggest that a method be designed for using early-flush releases and that the maximum sulfide oxidation rates from laboratory testing could be used as potentially worst case scenarios when applying lab results to the field.

In addition, scaling factors are sample- or lithology/mineralization-specific and appear to change throughout the HCT. Multiple scaling factors are needed for different elements and at different times of the year to "match" field conditions. For example, Bornhorst and Logsdon (2016) found that applying a simple conceptual model to steady-state HCT results, including scaling factors, produced results that overestimated field concentrations after 52 years of weathering. In another study, Lapakko and Olson (2015) found 714 distinct scaling factors that varied overall by a factor of about 20 for just one constituent, $\mathrm{SO}_{4}$, using the ratios of average 
release rates for matched field and laboratory experiments (rates from 17 lab tests $\times 42$ field rates). The field rates were average annual rates, and the variability in the scaling factors would have been even higher if winter field rates had been included. Metals and $\mathrm{pH}$ values followed different patterns and had more variability than $\mathrm{SO}_{4}$ concentrations throughout field testing. Such complications lessen the value of using scaling factors to predict mine waste environmental behavior. Further, using annual average field and laboratory rates does not consider the full variability in release rates or streamflow, which taken together control metal concentrations in streams.

\subsection{Salt dissolution and inverse modeling}

The elevated concentrations of constituents ("early flush") in the early weeks of humidity cell testing are often ignored when interpreting the results. Langman et al. (2014) attributed such concentrations to fine particles and mineral surfaces made reactive from mining. They and other practitioners (e.g., SRK Consulting, 2007 for the PolyMet samples in this study; Lapakko and White, 2000) use higher-volume flushes for the first several weeks of testing to remove any particles and reaction products. In the field, however, the weathering products of sulfide oxidation (especially soluble sulfate salts) can be present intermittently throughout the year and repeatedly from year to year and have a strong effect on mine drainage quality.

\subsubsection{Preliminary review of general cation-anion associations}

The mineralogy of secondary minerals is rarely if ever investigated as part of humidity cell testing. We found no information on sulfate minerals and little information on the presence or absence of other secondary minerals for the selected HCT samples. As a first step, and using measured major cation, anion, and dissolved metal concentrations and WATEQ4F results for 
solid phases and SI values, hand calculations were completed to evaluate the most likely minerals dissolving in early flush HCT samples. The results are shown in Table 5 with the results from inverse modeling.

The most important anion in all selected HCT samples was $\mathrm{SO}_{4}$ (Table 5). For early-flush Pebble and Buckhorn samples, Ca was the cation with the highest concentration in one of two Pebble and the two Buckhorn samples. Magnesium had the highest cation concentration in Pebble sample 025-0617-0637. Based on the relative abundance of ions, the solubility of sulfate minerals, and the negative gypsum SI, gypsum is the most likely dissolving mineral in the Pebble and Buckhorn samples. Although Ca could be dissolving from aluminosilicates later in the test, anorthite (for example) dissolution with pyrite oxidation will not produce congruent 1:1 ratios of $\mathrm{Ca}: \mathrm{SO}_{4}$. In addition, gypsum or anhydrite are tend to be more common than anorthite in the mineral deposits we are considering. Assuming 1:1 molar ratios for cations and $\mathrm{SO}_{4}, \mathrm{Ca}$ alone accounted for between 18 to $39 \%$ of the $\mathrm{SO}_{4}$ in the Pebble early flush samples and between 67 to $87 \%$ of the $\mathrm{SO}_{4}$ in the Buckhorn early-flush samples (Table 5). Combined $\mathrm{Mg}$ and $\mathrm{Ca}$ concentrations accounted for 74 to $78 \%$ (Pebble) and 79 to $97 \%$ (Buckhorn) of the $\mathrm{SO}_{4}$. Adding $\mathrm{Na}, \mathrm{K}$ (likely from dissolution of $\mathrm{K}$ feldspar), and metals, and assuming a 1:1 Cu:Fe sulfate mineral (e.g., chalcanthite and melanterite) accounted for the remainder of the ion load. In the PolyMet early-flush samples, the major cations were Fe or Na (Table 5). Assuming a 1:1 molar ratio, Fe alone accounts for $72 \%$ of the $\mathrm{SO}_{4}$ in the first PolyMet sample, and the most likely dissolving phases are melanterite $\left(\mathrm{FeSO}_{4} \cdot 7 \mathrm{H}_{2} \mathrm{O}\right)$ or nickeloan melanterite $\left.(\mathrm{Fe}, \mathrm{Ni}) \mathrm{SO}_{4} \cdot 7 \mathrm{H}_{2} \mathrm{O}\right)$. Nickeloan melanterite efflorescent crusts have been identified in the Sudbury area, which hosts a similar mafic/ultramafic base metal deposit (Rutstein, 1980). The other two PolyMet samples 
had the highest $\mathrm{pH}$ values of the early-flush samples and are similar in cation and anion composition. Sulfate is still the major anion, but bicarbonate and chloride are also present, and $\mathrm{Na}$ is the dominant cation, suggesting that sodium/calcium sulfate and carbonate, and possibly even chloride and hydroxide, minerals could be the dissolving phases.

\subsubsection{Inverse modeling and molar ratios}

Inverse modeling provides a more quantitative assessment of the cation-anion balances. Inverse modeling using PHREEQC with the WATEQ4F database was used to examine possible dissolving phases that might control water quality. Water chemistry results from the HCT samples with the highest early-flush concentrations were used as inputs to PHREEQC, and possible sulfate, chloride, and carbonate minerals were selected as potentially dissolving phases (Table 5). The choices were based on the available phases in PHREEQC (NETPATH) and known field occurrences from the literature; choices also needed to be consistent with the solution chemistry, and the SI values from WATEQ4F were used as a guide. The uncertainty was set at 1.0 (highest setting), which suggests that the results are rough approximations. Gypsum was the mineral with the highest number of moles transferred for the Pebble and the Buckhorn early flush samples. For the Pebble sample, melanterite was the only other phase with moles transferred. For the Buckhorn sample, epsomite, halite, and dolomite were identified as possible dissolving phases. For the PolyMet sample, gypsum was predicted to be less important as a dissolving phase, and halite, calcite, and epsomite were more important. The results suggest that sulfate, chloride, and carbonate salts can explain a substantial portion of the observed solute concentrations in the early flush samples. 
Table 5. Major anions and cations and pH values of early-flush $\mathrm{HCT}$ samples and percent $\mathrm{SO}_{4}$ accounted for, on an equivalence basis, by various cations.

\begin{tabular}{|c|c|c|c|c|c|c|c|c|c|}
\hline \multirow[b]{2}{*}{ Site } & \multirow[b]{2}{*}{ Sample } & \multirow[b]{2}{*}{ Week } & \multirow[b]{2}{*}{$\begin{array}{l}\mathrm{pH} \\
(\mathrm{SU})\end{array}$} & \multirow[b]{2}{*}{$\begin{array}{l}\text { Major } \\
\text { Anions }^{a}\end{array}$} & \multirow[b]{2}{*}{ Major Cations ${ }^{a}$} & \multicolumn{4}{|c|}{$\% \mathrm{SO}_{4}$ accounted for by: } \\
\hline & & & & & & Cation 1 & Cation $1 \& 2$ & Cation 1to3 & $\begin{array}{c}\text { Remaining } \\
\text { Cations }\end{array}$ \\
\hline Pebble & $\begin{array}{l}025-0617- \\
0637\end{array}$ & 0 & 4.03 & $\mathrm{SO}_{4}>\mathrm{Cl}$ & $\begin{array}{l}\mathrm{Mg}>\mathrm{Ca}>\mathrm{Mn}>\mathrm{Cu}> \\
\mathrm{Al}>\mathrm{Fe}>\mathrm{Zn}>\mathrm{K}\end{array}$ & $56 \%$ & $74 \%$ & $81 \%$ & $89 \%$ \\
\hline
\end{tabular}

Saturated possible secondary minerals (SI) - WATEQ4F ${ }^{c}$ : alunite (3.3), barite (0.71), gypsum (-0.13), anhydrite (-0.35), kaolinite (-0.88), gibbsite (-0.89)

\begin{tabular}{|c|c|c|c|c|c|c|c|c|c|}
\hline Pebble & $\begin{array}{l}\text { 3069-0927- } \\
0947\end{array}$ & 0 & 3.95 & $\begin{array}{l}\mathrm{SO}_{4}>>\mathrm{Cl}> \\
\mathrm{HCO}_{3}\end{array}$ & $\begin{array}{l}\mathrm{Ca}>\mathrm{Mg}>\mathrm{Cu}>\mathrm{Mn}>> \\
\mathrm{K}>\mathrm{Al}>\mathrm{Fe}\end{array}$ & $39 \%$ & $78 \%$ & $88 \%$ & $98 \%$ \\
\hline \multicolumn{10}{|c|}{ Saturated possible secondary minerals (SI) - WATEQ4F': alunite $(1.34)$, barite (1.08), gypsum (-0.54), anhydrite $(-0.76)$, gibbsite $(-1.57$} \\
\hline Buckhorn & $\mathrm{HC}-1$ & 1 & 6.40 & $\mathrm{SO}_{4}>\mathrm{Cl}$ & $\mathrm{Ca}>\mathrm{Mg}>\mathrm{Na}>\mathrm{K}>\mathrm{Mn}$ & $87 \%$ & $97 \%$ & $104 \%$ & $106 \%$ \\
\hline
\end{tabular}

Saturated possible secondary minerals (SI) - WATEQ4F': gibbsite (c) (1.34), alunite (0.94), gibbsite (uc) (0.10), barite (-0.31),

basaluminite $(-0.40)$, gypsum $(-0.79)$, anhydrite $(-1.0), \mathrm{Al}(\mathrm{OH})_{3}(\mathrm{a})(-1.35)$

\begin{tabular}{llllllllll}
\hline Buckhorn & $\mathrm{HC}-8$ & 0 & 7.05 & $\mathrm{SO}_{4}>\mathrm{Cl}$ & $\mathrm{Ca}>\mathrm{Mg}>\mathrm{Na}>\mathrm{K}>\mathrm{Mn}$ & $67 \%$ & $79 \%$ & $87 \%$
\end{tabular}

Saturated possible secondary minerals (SI) - WATEQ4F ${ }^{c}$ : gibbsite (c) (1.26), gibbsite (uc) (0.02), barite (0.15), tenorite (-0.59), gypsum $(-0.75)$, alunite $(-0.79)$, anhydrite $(-0.97), \mathrm{Al}(\mathrm{OH})_{3}(\mathrm{a})(-1.43)$, basaluminite $(-1.90)$

\begin{tabular}{|c|c|c|c|c|c|c|c|c|c|}
\hline PolyMet & $\begin{array}{l}337 C(510- \\
520)\end{array}$ & 10 & 4.27 & $\mathrm{SO}_{4}$ & $\mathrm{Fe}>\mathrm{Mg}>\mathrm{Na}>\mathrm{Ca}>\mathrm{Ni}$ & $72 \%$ & $83 \%$ & $92 \%$ & $104 \%$ \\
\hline \multicolumn{10}{|c|}{$\begin{array}{l}\text { Saturated possible secondary minerals (SI) - } \\
(-1.93) \text {, anhydrite }(-2.05) \text {, celestine }(-2.08)\end{array}$} \\
\hline PolyMet & $\begin{array}{l}367-(400- \\
405)\end{array}$ & 2 & 8.71 & $\begin{array}{l}\mathrm{SO}_{4}>\mathrm{HCO}_{3}> \\
\mathrm{Cl}\end{array}$ & $\mathrm{Na}>\mathrm{Ca}>\mathrm{K}$ & $93 \%$ & $108 \%$ & $114 \%$ & $114 \%$ \\
\hline
\end{tabular}


Saturated possible secondary minerals $(\mathrm{SI})$ - WATEQ4F : gibbsite (c) $(0.65)$, allophane (p) (0.07), calcite (-0.37), otavite (-0.37), barite $(-0.48)$, aragonite $(-0.52)$, gibbsite (uc) $(-0.59)$, tenorite $(-0.75)$, allophane (a) $(-1.03)$, dolomite (c) $(-1.11)$, rhodochr. (c) $(-1.22)$, cerrusite (-1.30), magnesite (-1.32), dolomite (d) $(-1.66), \mathrm{Cu}(\mathrm{OH})_{2}(-1.77)$, rhodochr. (d) $(-1.9), \mathrm{Al}(\mathrm{OH})_{3}(\mathrm{a})(-2.04)$, gypsum (-2.55)

\begin{tabular}{lllllllll}
\hline PolyMet & $\begin{array}{l}26027 \\
(616-626)\end{array}$ & 2 & 8.09 & $\begin{array}{l}\mathrm{SO}_{4}>\mathrm{Cl}> \\
\mathrm{HCO}_{3}\end{array}$ & $\mathrm{Na}>\mathrm{Ca}>\mathrm{Mg}>\mathrm{K}$ & $44 \%$ & $70 \%$ & $107 \%$ \\
\hline
\end{tabular}

Saturated possible secondary minerals $(\mathrm{SI})$ - WATEQ4F : allophane $(\mathrm{p})(0.24)$, barite $(-0.22)$, allophane $(\mathrm{a})(-0.76)$, tenorite $(-0.76)$, calcite (-0.81), aragonite (-0.96), rhodochr. (c) (-1.21), otavite (-1.24), cerrusite (-1.32), $\mathrm{Al}(\mathrm{OH})_{3}(\mathrm{a})(-1.63)$, dolomite (c) (-1.78), rhodochr. (d) (-1.95), gypsum (-2.21), dolomite (d) (-2.33)

a Major defined as $>10^{-5} \mathrm{eq} \mathrm{L}^{-1}$; b Sum of major anions used for the Buckhorn and last two PolyMet samples; $\mathrm{c}$ In order of decreasing saturation index (SI; Log IAP/KT). 
Because of the importance of gypsum as a dissolving phase in early-flush samples, $\mathrm{Ca}: \mathrm{SO}_{4}$ molar ratios were examined for the first 60 weeks of humidity cell testing. The major common cations ( $\mathrm{Ca}, \mathrm{Mg}, \mathrm{Na}, \mathrm{K}$, and $\mathrm{Cu}$ for Pebble) and anions $\left(\mathrm{SO}_{4}\right.$ only for Pebble and Buckhorn, and $\mathrm{SO}_{4}$ and bicarbonate for PolyMet) were plotted for the first 60 weeks of HCT testing in Figure 5. The $\mathrm{Ca}: \mathrm{SO}_{4}$ molar ratio, or, for the Pebble sample the sum of major cations: $\mathrm{SO}_{4}$ molar, was also plotted to examine possible sulfate salt solubility controls. In the Pebble sample, $\mathrm{Ca}$ and $\mathrm{Mg}$ concentrations varied between 50 to $80 \%$ of total cations, averaging about $60 \%$ for the first 60 weeks. Figure 5 a shows that the major cation: $\mathrm{SO}_{4}$ molar ratio remained close to one for the Pebble sample throughout the first year or more of testing, suggesting that dissolution of gypsum and other sulfate salts was a major controlling factor in observed leachate chemistry. After 60 weeks (data not shown), the major cations: $\mathrm{SO}_{4}$ ratio decreased as $\mathrm{SO}_{4}$ concentrations rose, and the ratio remained between 0.1 and 0.2 for the remainder of the test. For the Buckhorn Mine sample, $\mathrm{Ca}$ and $\mathrm{SO}_{4}$ concentrations tracked each other closely, and the $\mathrm{Ca}: \mathrm{SO}_{4}$ molar ratio remained close to one, with substantial variability, for the first 35 weeks of testing (Figure 5b). After this point, the ratio decreased, and $\mathrm{SO}_{4}$

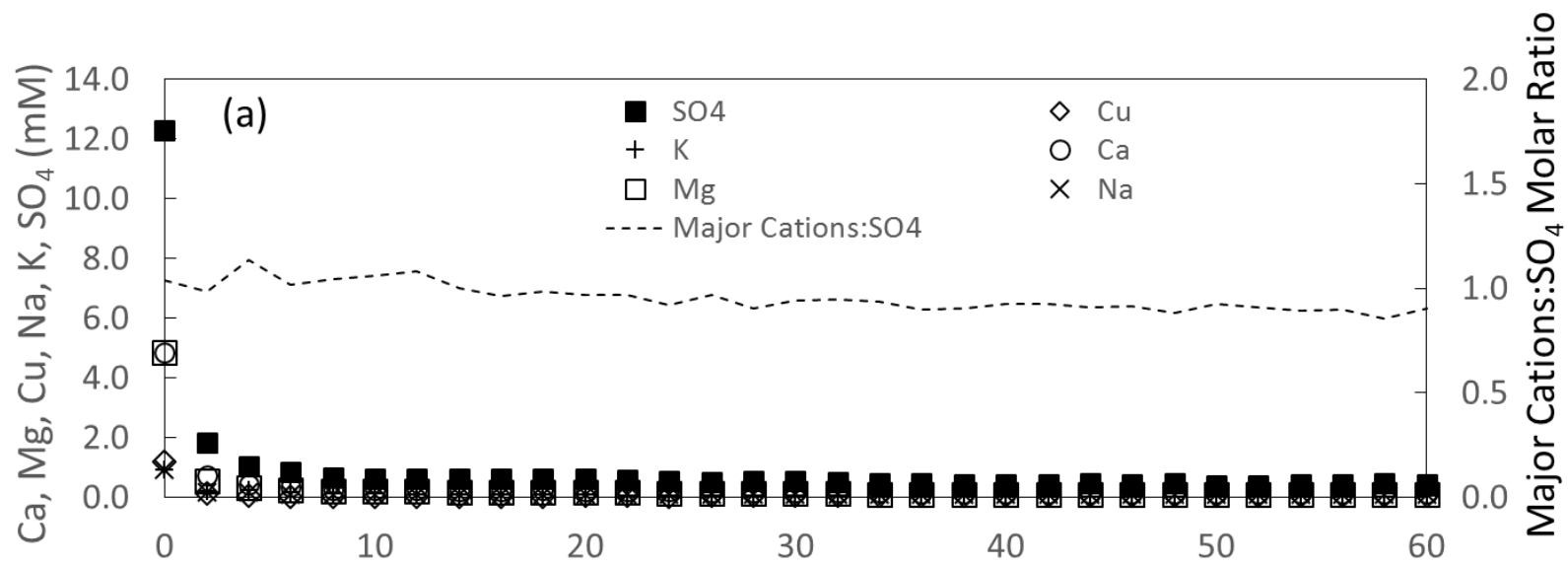



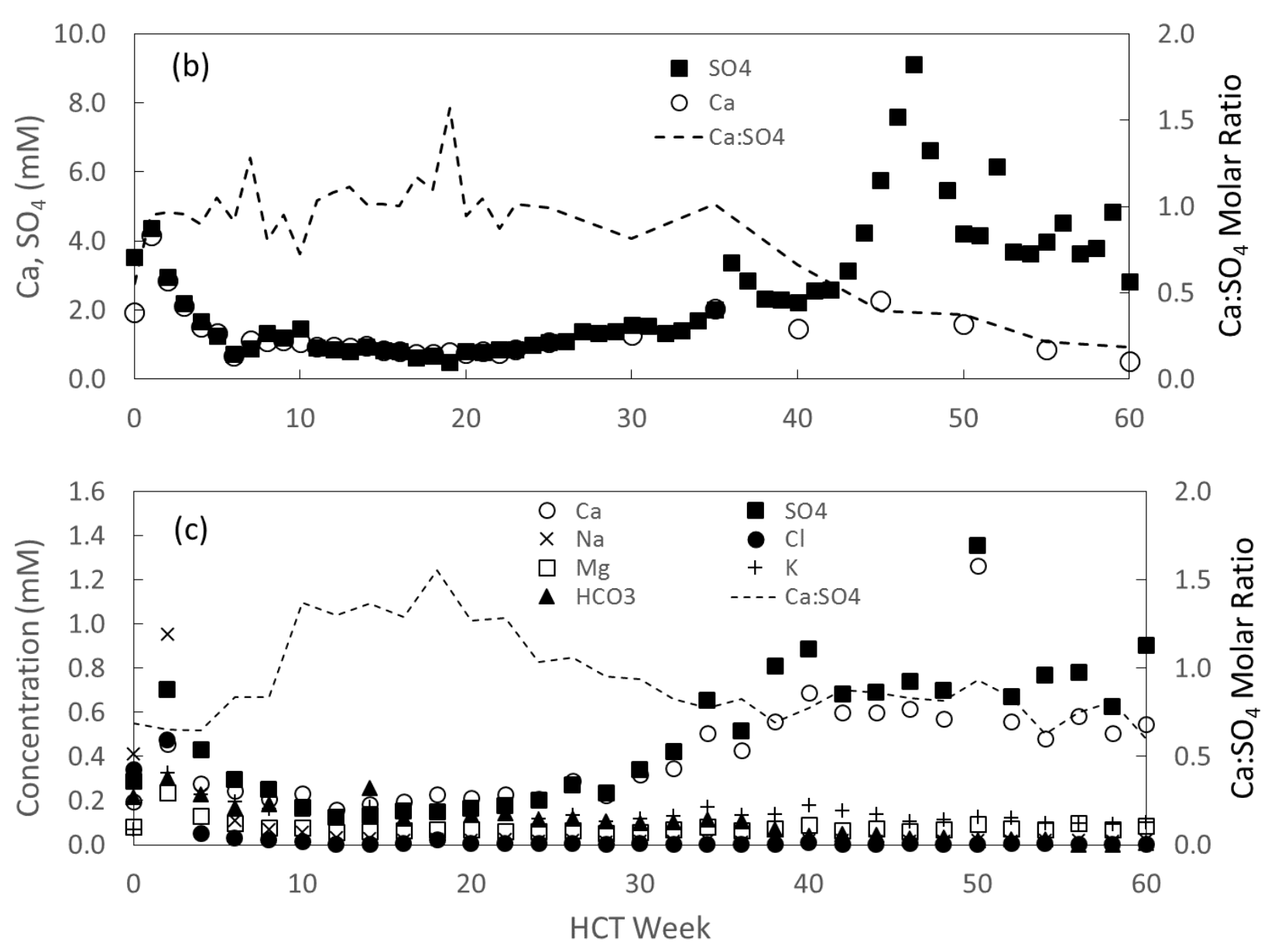

Figure 5. Salt dissolution in first 60 weeks of HCT testing: (a) Pebble Project sample 3069-0927-0947; (b) Buckhorn Mine sample HC-1; and (c) PolyMet Project sample 26027(616-626)

concentrations rise sharply (weeks 43 to 47 ) as the $\mathrm{pH}$ dropped below 4.0 and Fe concentrations increased. Trends were very similar for the Pebble sample after HCT week 120.

The PolyMet sample was less controlled by gypsum dissolution early in the test, as shown in the results of inverse modeling (Table 6 ). However, as shown in Figure $5 \mathrm{c}, \mathrm{Ca}$ and $\mathrm{SO}_{4}$ concentrations tracked each other starting in week 6 and remained linked throughout the remaining approximately 50 weeks of testing shown in Figure $5 c$. The results suggest that gypsum solubility can mask sulfide dissolution and oxidation because of the elevated $\mathrm{SO}_{4}$ concentrations, as noted by Price (2009) and others. 
Gypsum dissolution can come from primary anhydrite that has been rehydrated after original mineral formation in the deposit, or anhydrite can dissolve directly. Alternatively, gypsum can form from the reaction between co-existing pyrite and calcite (e.g. Plumlee et al., 2009). In these three examples, testing was needed for at least one year. The revised ASTM HCT method (ASTM, 2013) recommends analyzing concentrations of $\mathrm{SO}_{4}$ and other solutes every other week for 20 weeks (or weekly, if feasible), every four weeks through week 40, and at least every eight weeks thereafter. More frequent analysis will help distinguish sulfate salt dissolution from rapid $\mathrm{SO}_{4}$ increases that signal sulfide oxidation.

Table 6. Inputs to and results from PHREEQC inverse modeling (using NETPATH) for Pebble Project, Buckhorn Mine, and PolyMet Project HCT samples with highest early-flush concentrations

\begin{tabular}{|c|c|c|c|c|c|c|c|}
\hline Project & Sample ID & Week & $\mathrm{Cl} \%$ & $\begin{array}{l}\text { Cond. } \\
(\mu \mathrm{S} / \mathrm{cm})\end{array}$ & $\begin{array}{l}\text { Field } \\
\mathrm{pH} \\
\text { (SU) } \\
\end{array}$ & $\begin{array}{l}\text { Input: } \\
\text { Phases } \\
\text { selected }\end{array}$ & $\begin{array}{c}\text { Output: } \\
\text { mmol kg } \mathrm{H}_{2} \mathrm{O}^{-1} \\
\text { transferred }\end{array}$ \\
\hline \multirow[t]{4}{*}{ Pebble } & 3069-0927- & 0 & 5.97 & 1491 & 3.95 & gypsum & 4.84 \\
\hline & 0947 & & & & & melanterite & 0.22 \\
\hline & & & & & & chalcanthite & NA \\
\hline & & & & & & manganite & NA \\
\hline \multirow[t]{6}{*}{ Buckhorn } & $\mathrm{HC}-1$ & 1 & -9.81 & 600 & 6.4 & gypsum & 4.07 \\
\hline & & & & & & epsomite & 0.71 \\
\hline & & & & & & halite & 0.39 \\
\hline & & & & & & dolomite & 0.10 \\
\hline & & & & & & pyrolusite & NA \\
\hline & & & & & & mirabilite & NA \\
\hline \multirow[t]{5}{*}{ PolyMet } & 26027(616- & 2 & 20.9 & 274 & 8.01 & halite & 0.48 \\
\hline & 626) & & & & & calcite & 0.30 \\
\hline & & & & & & epsomite & 0.24 \\
\hline & & & & & & gypsum & 0.16 \\
\hline & & & & & & dolomite & NA \\
\hline
\end{tabular}

$N A=$ mineral was not predicted to dissolve according to model results. 


\section{Summary and Conclusions}

\subsection{Overall geochemical reactions throughout the HCTs}

The overall geochemical reactions for the three primary HCT samples used throughout the paper are discussed in this section and summarized in Table 7. The sequence of geochemical reactions is similar for HCT results from the three sites, primarily because they all produced acid drainage (that subsequently reacts with the non-sulfide gangue). The formation of secondary minerals in sulfidic material begins with the oxidation of sulfide minerals and the interaction of acidic drainage with the rest of the matrix. Under unsaturated conditions in a waste rock pile, for example, the pore water evapoconcentrates and precipitates highly soluble, ephemeral secondary salts. The salts accumulate in the pore space during dry or winter seasons when through-flow is insufficient to dissolve and transport the mass. During the wet or snowmelt season, infiltrating waters dissolve and transport the salts as effluent. In the HCTs examined, secondary salts had a variable effect on leachate quality, depending on the geology and mineralization of the materials used, the types and abundance of weathering products produced, their weathering rates, and the degree of dilution of early-flush samples. The HCT concentrations over time can be thought of as a "chromatogram" of reactions that occur in the field, running from sulfate salt dissolution through sulfide oxidation to dissolution of rockforming and neutralizing minerals. Some of these reactions occur simultaneously, such as oxidation of sulfides and precipitation of ferric hydroxide coatings, but through geochemical evaluation they can be distinguished. 
One of the most important differences between HCT and larger-scale field leachate, however, is the repetition of these processes, especially the cycling of secondary minerals through evaporation and dissolution on a seasonal basis. As currently designed, the early flush seen in the HCT results occurs only once over a limited period in the tests, whereas under field conditions solute flushes would repeat on a seasonal

Table 7. Summary of geochemical processes observed

\begin{tabular}{|c|c|c|c|}
\hline \multicolumn{2}{|c|}{ Mine Project and Testing Information } & \multicolumn{2}{|l|}{ Overall Geochemical Processes } \\
\hline $\begin{array}{l}\text { Mine or Project, } \\
\text { Location (USA) }\end{array}$ & $\begin{array}{l}\text { Mine Type; Sample } \\
\text { ID; Rock Type }\end{array}$ & Geochemical Processes Observed & Weeks \\
\hline \multirow{5}{*}{$\begin{array}{l}\text { Pebble Project, } \\
\text { Alaska; Pebble West }\end{array}$} & \multirow{5}{*}{$\begin{array}{l}\text { Copper-gold; 3069- } \\
\text { 0927-0947; Pre- } \\
\text { Tertiary/ } \\
\text { Granodiorite }\end{array}$} & $\begin{array}{l}\text { Initial sulfate salt dissolution and } \mathrm{pH} \\
\text { increase/gypsum dissolution }\end{array}$ & $0-10 / 0-60$ \\
\hline & & Acid formation & $0-294$ \\
\hline & & Rapid chalcopyrite/pyrite dissolution & $115-139$ \\
\hline & & $\begin{array}{l}\text { Decrease in metal and } \mathrm{SO}_{4} \text { concentrations - } \\
\text { precipitation of } \mathrm{Fe} \text { oxyhydroxide }\end{array}$ & $145-294$ \\
\hline & & $\begin{array}{l}\text { Concentration and buffering at low } \mathrm{pH} \text { (2.4- } \\
\text { 2.9) by dissolution of Fe hydroxides }\end{array}$ & $142-294$ \\
\hline \multirow{5}{*}{$\begin{array}{l}\text { Buckhorn Mine, } \\
\text { Washington; Gold } \\
\text { Bowl }\end{array}$} & \multirow{5}{*}{$\begin{array}{l}\text { Gold; HC-1 GB-C13- } \\
\text { 419; Magnetite skarn }\end{array}$} & $\begin{array}{l}\text { Initial metal-sulfate salt dissolution and } \mathrm{pH} \\
\text { buffering (6.7-7.4 after initial } \mathrm{pH} \text { of } 6.4)\end{array}$ & $0-35$ \\
\hline & & Acid formation & $30-170$ \\
\hline & & Rapid pyrrhotite dissolution & $40-50$ \\
\hline & & $\begin{array}{l}\text { Decrease in metal and } \mathrm{SO}_{4} \text { concentrations - } \\
\text { precipitation of Fe oxyhydroxide }\end{array}$ & $48-98$ \\
\hline & & $\begin{array}{l}\text { Concentration and pH buffering (2.3-2.9) by } \\
\text { Fe oxyhydroxide }\end{array}$ & $96-173$ \\
\hline \multirow{6}{*}{$\begin{array}{l}\text { PolyMet Project, } \\
\text { Minnesota }\end{array}$} & \multirow{6}{*}{$\begin{array}{l}\text { Copper-nickel-PGE; } \\
26027(616-626) ; \\
\text { Anorthositic } \\
\text { troctolite }\end{array}$} & Initial carbonate and chloride salt dissolution & $0-50$ \\
\hline & & Acid formation with some $\mathrm{pH}$ buffering & $24-332$ \\
\hline & & Rapid pyrrhotite/Ni-pyrrhotite dissolution & $172-194$ \\
\hline & & $\begin{array}{l}\mathrm{pH} \text { buffering (at approximately } 4 \text { ) by } \\
\text { aluminosilcates }\end{array}$ & $178-332$ \\
\hline & & Mg-olivine dissolution & $228-332$ \\
\hline & & 57 & \\
\hline
\end{tabular}


basis, driven by site hydrology and meteorologic conditions. Although the most obvious effect of secondary minerals occurs during the HCT early flush, the dissolution of these minerals can last throughout the test and mask sulfide oxidation. Methods for separately considering the effect of secondary minerals on HCT data should be designed because for sulfide ore bodies and wastes containing weatherable sulfides, these same geochemical reactions will occur repeatedly under field testing and mine operational conditions. Removing the secondary minerals from the test materials is not advised (see, e.g., Lapakko et al., 2004; Lapakko and White, 2000; Langman et al., 2014), if one of the goals is to understand and predict leachate quality over time. The extent of sulfate salts present in an HCT sample is influenced by the length of time the sample was stored prior to testing and the oxidation that occurred during storage. To better mimic the variety of geochemical reactions that can occur in the field, the samples should be stored for a sufficient amount of time to oxidize sulfides and form secondary sulfate minerals.

\subsubsection{Pebble Project}

Sulfate and $\mathrm{Cu}$ concentrations peaked during the first week of testing and decreased as $\mathrm{pH}$ values rose (see Figure 2a). Week 0 results showed high $\mathrm{Ca}, \mathrm{Mg}$, and $\mathrm{SO}_{4}$ concentrations, suggesting that $\mathrm{Ca}$ and $\mathrm{Mg}$ sulfate salts, which generate no acidity or pH-buffering, were being dissolved. Based on the lack of Fe-containing minerals other than sulfides and the initial moderate $\mathrm{pH}$ values, the salts were formed from oxidation of pyrite and dissolution of carbonate. Initial minor peaks in $\mathrm{K}$ and $\mathrm{Cu}$ likely resulted from the dissolution of the abundant 
and altered $\mathrm{K}$ feldspar and trace chalcopyrite, respectively. More residual acidity remained, based on the mildly acidic $\mathrm{pH}(3.95)$ in the first week of testing. In subsequent weeks, the sulfate salts continued to dissolve, and the $\mathrm{pH}$ rose from dilution. According to detailed mineralogic analysis, no carbonates were present in the sample before or after the HCT was conducted (PLP, 2011a), but some minor carbonate was probably present before the weathering products were formed. The majority of the Ca in the first 60 weeks of the test was most likely associated with dissolution of secondary gypsum rather than carbonates during the actual HCT test, based on the mineralogic analysis, the lack of detectable alkalinity, and the approximate 1:1 molar ratio of $\mathrm{Ca}$ and $\mathrm{SO}_{4}$ through week 60 (see Figure 5a). The $\mathrm{pH}$ dropped from approximately 4.5 to 2.4 over a 120 -week period and then stabilized between $\mathrm{pH} 2.5$ and 3.0 for the remainder of the 294-week test (Figure 6). The low-pH buffering can be attributed to an equilibrium buffering with ferric hydroxide minerals (Nordstrom and Campbell, 2014), as indicated by the low and relatively constant ferrihydrite SI (see Figure 2a). Right before $\mathrm{pH}$ values stabilized at lower $\mathrm{pH}$ values, $\mathrm{Fe}$ and $\mathrm{SO}_{4}$ concentrations rose as a result of more rapid pyrite oxidation that could have been assisted by dissolution of Fe hydroxide coating on the sulfides. 


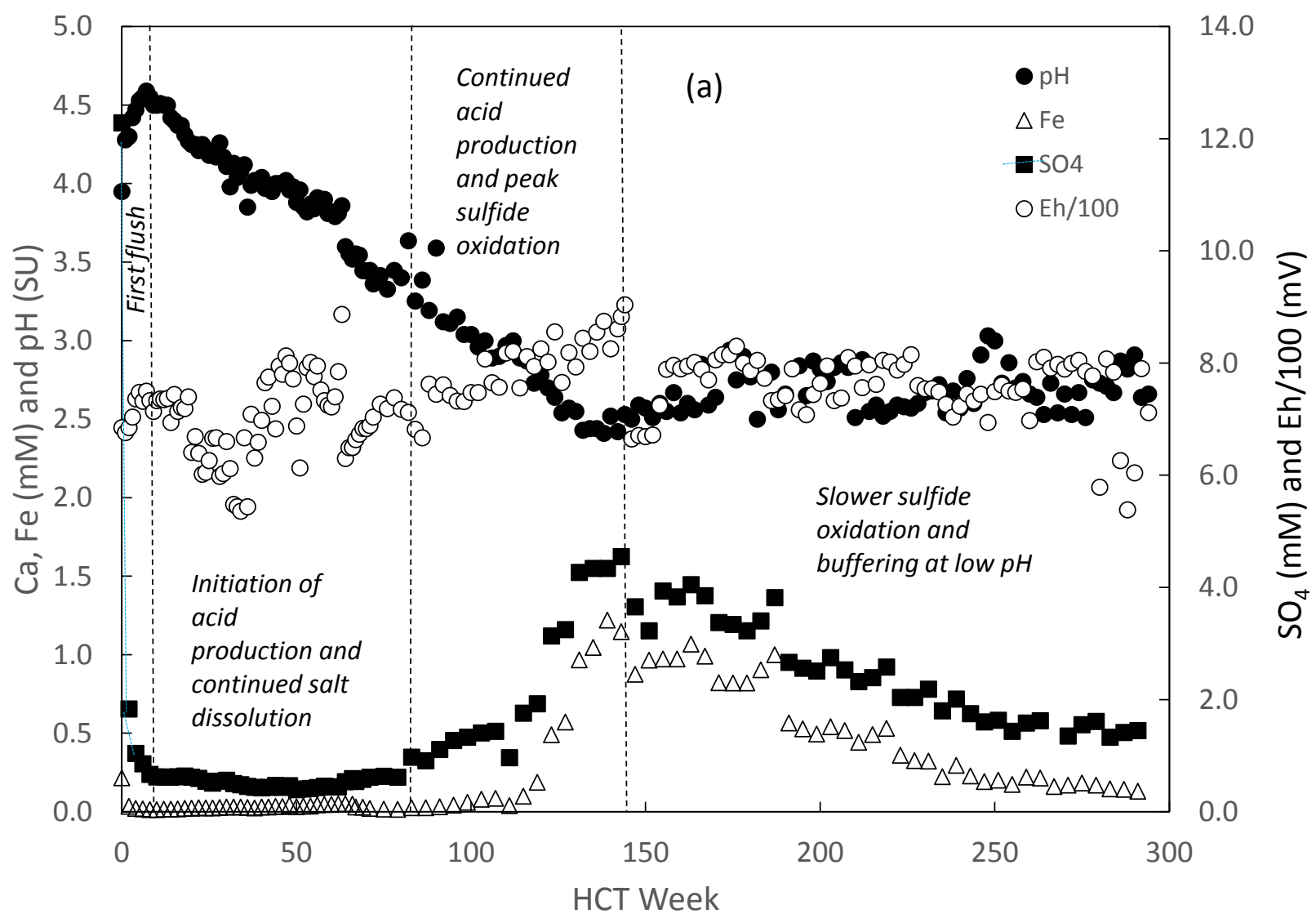

Figure 6. Geochemical processes operating in humidity cell tests, Pebble Project sample 3069-09270947, granodiorite, trickle leach, $2.44 \%$ sulfide

Iron and $\mathrm{SO}_{4}$ concentrations decreased from weeks 142 to 294 and stabilized somewhat in the last 40 weeks of the test, consistent with ferrous Fe oxidation and precipitation of ferric hydroxide. The $\mathrm{pH}$ was not low enough for jarosite precipitation (should be close to or $<2$, Baron and Palmer, 1996; Dutrizac, 2008), and jarosite was not identified in the post-HCT mineralogic analysis (PLP, 2011a). If the sulfide grains were coated with ferric hydroxide precipitate, sulfide oxidation rates would decrease (Langman et al., 2014), and $\mathrm{SO}_{4}$ concentrations would also be expected to decrease, as observed. As noted in Section 4.3.3, an orange-red or -brown precipitate, identified as possibly limonite, was observed in the post-HCT mineralogic analysis of the sample. WATEQ4F output showed that $\mathrm{K}$ jarosite was 
supersaturated for many of the test weeks, but $\mathrm{K}$ concentrations did not follow $\mathrm{SO}_{4}$ trends, the $\mathrm{pH}$ values were generally too high for jarosite precipitation, and jarosite, unlike gypsum, is known to be supersaturated in natural waters (Nordstrom and Munoz, 1994).

\subsubsection{Buckhorn Mine}

Buckhorn Mine HCT samples HC-1 and HC-8 are skarns but have low carbonate content and acid neutralization potential (NP values for the two samples are 11 and 13 tons $\mathrm{CaCO}_{3} / 1000$ tons, respectively). Pyrrhotite is the dominant Fe sulfide mineral in the deposit. For HC-1, the approximate 1:1 $\mathrm{Ca}: \mathrm{SO}_{4}$ molar ratio from week 0 to week 35 indicated that gypsum was dissolving (see Figure 5b). Aside from the initial lower $\mathrm{pH}$, values remained above 7 through week 25 , suggesting that if pyrrhotite was dissolving, the low residual calcite was buffering any acid produced (Figure 7). After week 25 , any minor calcite was exhausted, and the $\mathrm{pH}$ dropped

to below 4 by week 45 . Between week 40 and 45 , dissolved $\mathrm{Fe}$ and $\mathrm{SO}_{4}$ concentrations began to increase and Fe reached its highest concentrations $(5 \mathrm{mM})$, indicating that pyrrhotite dissolution was dominant. After week 50, $\mathrm{Fe}$ and $\mathrm{SO}_{4}$ concentrations decreased, suggesting that hydrated ferric oxides were precipitating and limiting pyrrhotite dissolution by coating a portion of the grains and limiting oxygen diffusion. After this time, $\mathrm{SO}_{4}$ concentrations gradually increased because of continued sulfide oxidation, but Fe concentrations remained lower due to solubility constraints.

\subsubsection{PolyMet Project}

The PolyMet sample 26027(616-626) is considered lean ore and is an anorthositic troctolite with Ca-plagioclase>olivine> clinopyroxene (SRK Consulting, 2007; Tyson and Chang, 1984) and 
$1.83 \%$ total S. The early flush (weeks $0-2$ ) had elevated concentrations of $\mathrm{SO}_{4}, \mathrm{Ca}, \mathrm{Na}, \mathrm{K}, \mathrm{HCO}_{3}$, $\mathrm{Cl}$, and $\mathrm{Mg}$ (see Figure 5c). Calcium concentrations were lower than $\mathrm{SO}_{4}$ values, but $\mathrm{Ca}+\mathrm{Mg}$ accounted for most of the major anions during week 2 . The monotonic decrease in $\mathrm{pH}$ lasted from the beginning of the test to week 132, and the $\mathrm{pH}$ then stabilized at approximately 4 (Figure 8). The pH was buffered at approximately pH 4.2 until about week 178, then it dropped to below 4 (3.8). Aluminum concentrations increased somewhat

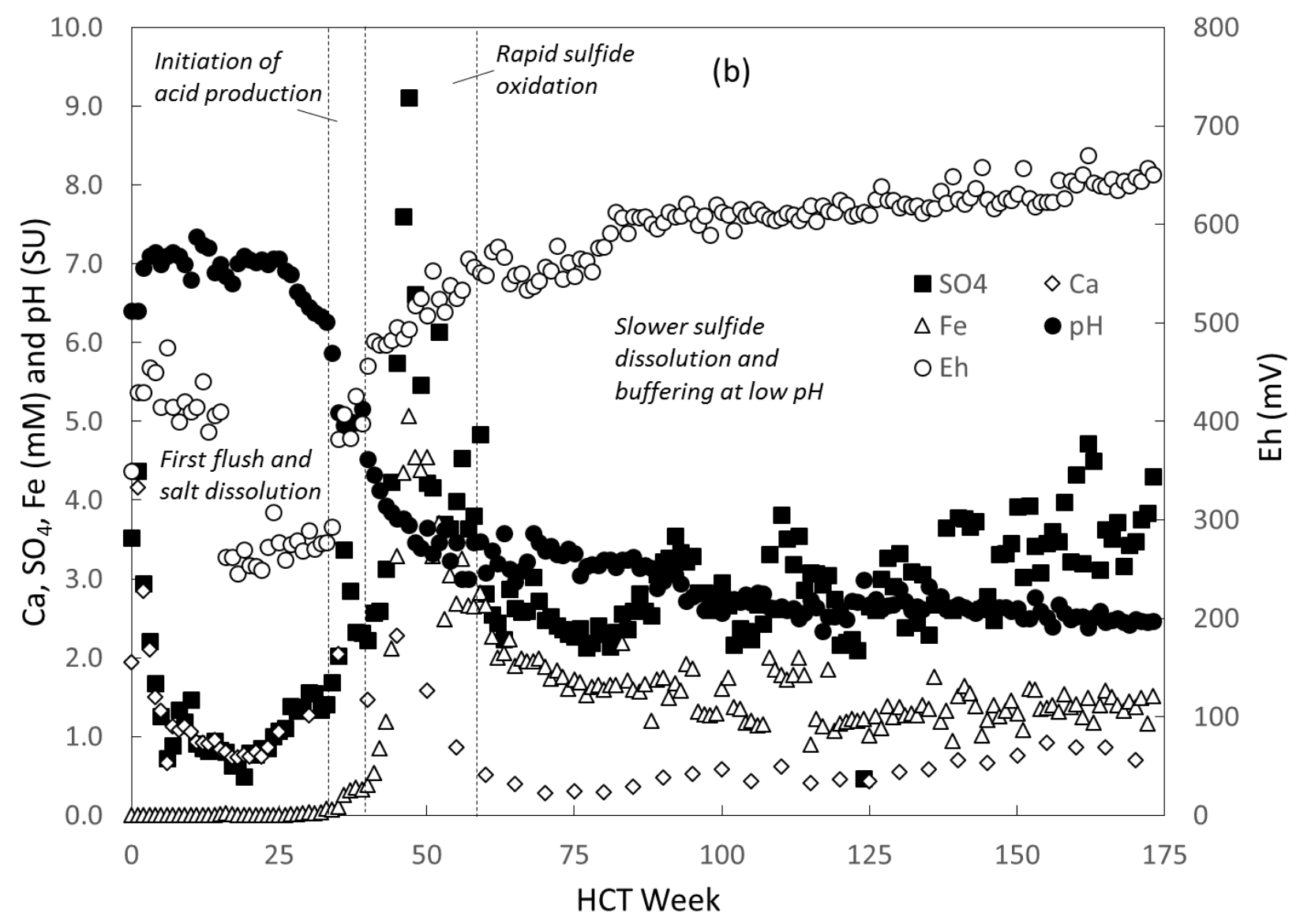

Figure 7. Geochemical processes operating in humidity cell tests, Buckhorn Mine, HC-1, magnetite skarn, flood leach, $1.91 \%$ sulfide 
starting in week 178 . This sample shows, better than the others, the buffering of $\mathrm{pH}$ by aluminum hydroxide minerals (Langman et al., 2014). Iron concentrations began to increase at approximately week 115 but had a faster increase when the $\mathrm{pH}$ dropped below 4 (week 172).

From weeks 172-194 Fe (and to a lesser degree, $\mathrm{Ni}$ - data not shown) concentrations increased, most likely from rapid oxidation of an Fe-containing sulfide. The $(\mathrm{Ni}+\mathrm{Fe}) / \mathrm{SO}_{4}$ ratio was too low for pentlandite, and the Ni was more likely associated with pyrrhotite. In the majority of sulfide deposits, $\mathrm{Ni}$ is associated with pentlandite, usually as tiny exsolution lamellae or thin discontinuous coatings in pyrrhotite (Naldrett et al., 1967). Nickel is present in olivine, pyrrhotite, and pentlandite (Lapakko et al., 2004), but microprobe analysis of over 200 sulfide and silicate mineral grains from the Duluth Complex showed that pentlandite was the primary $\mathrm{Ni}$-bearing mineral, with a median value of $32 \% \mathrm{Ni}$ in pentlandite, compared with $0.077 \% \mathrm{Ni}$ in olivine (SRK Consulting, 2007). The Mg concentrations decreased during these weeks, suggesting that the Ni was not associated with incongruent dissolution of Ni-rich olivine. In addition, $\mathrm{SO}_{4}$ concentrations far exceeded $\mathrm{Fe}+\mathrm{Ni}$ concentrations, even when $\mathrm{Ca}+\mathrm{Mg}$ concentrations were subtracted. Unlike the results for the other HCT samples in this study, the $\mathrm{SO}_{4}$ values were low and highly scattered. Our examination of the charge balances 


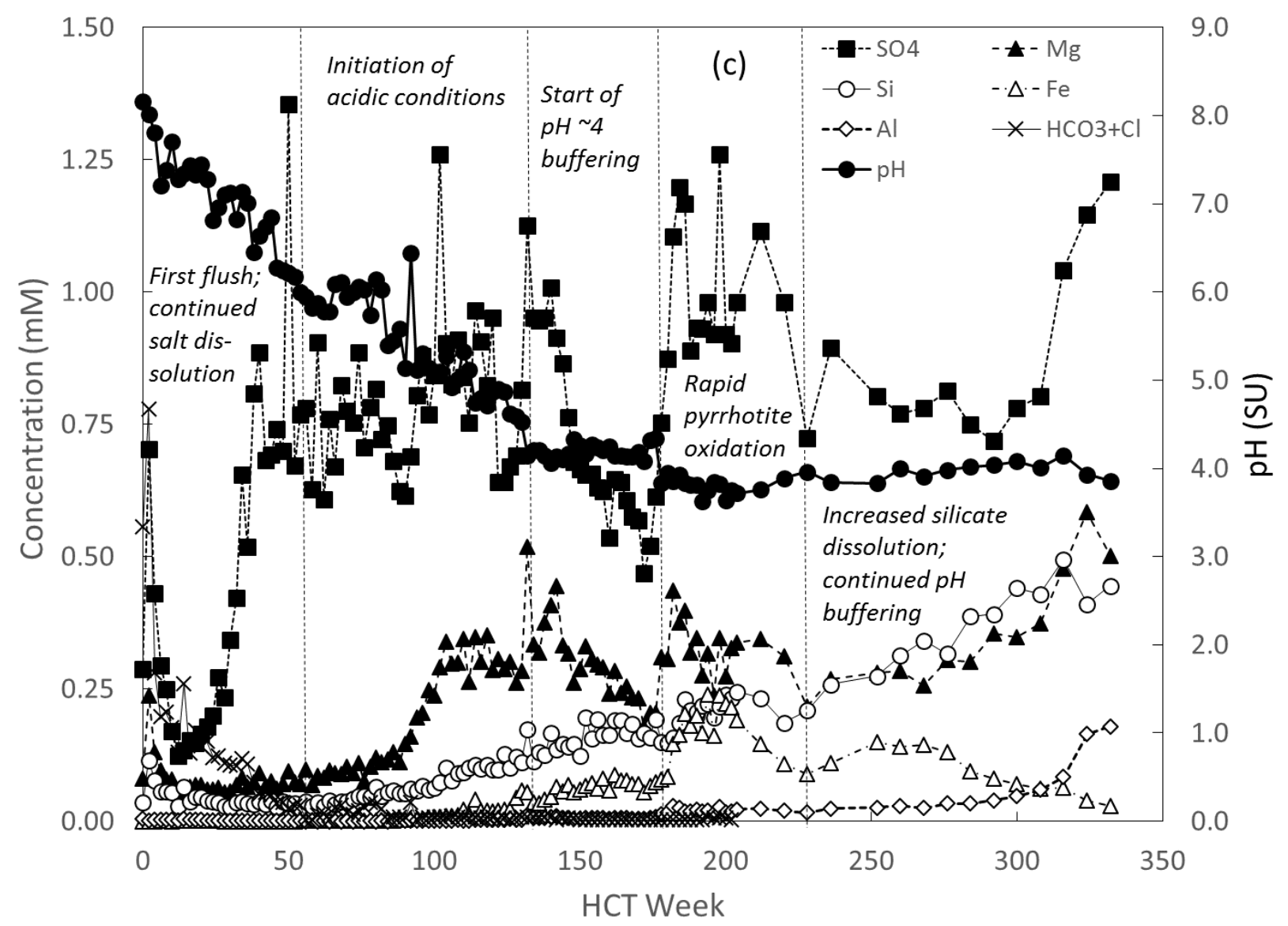

Figure 8. Geochemical processes operating in humidity cell tests, PolyMet Project, 26027(616-626), anorthositic troctolite, flood leach, $1.83 \%$ total S (sulfide S\% was not measured)

would suggest that the $\mathrm{SO}_{4}$ determinations were biased low and were imprecise. Consequently, we cannot adequately interpret the metal:sulfate ratios in the solutions with those in the likely solid phases. The formula for pyrrhotite, $\mathrm{Fe}_{(1-x)} \mathrm{S}$, can be estimated using the $\mathrm{S}$ :( $\left.\mathrm{Fe}+\mathrm{Ni}\right)$ ratio, or $n$, where $x$ in the pyrrhotite structure $=(n-1) / n$. The Cu-bearing sulfides chalcopyrite and cubanite in separate samples from Duluth Complex test piles near Babbitt, Minnesota, had Fe oxyhydroxide coatings that were approximately 10-micrometers thick (Lapakko et al., 2004), which could have suppressed dissolution of these sulfides and kept $\mathrm{Cu}$ leachate concentrations low. 
Near the end of the test, silica, $\mathrm{Mg}$, and $\mathrm{SO}_{4}$ concentrations rose, and the $\mathrm{pH}$ remained buffered very consistently at approximately 4 , most likely by an aluminosilicate mineral such as kaolinite or another clay, as suggested in the Questa, New Mexico, study (Nordstrom, 2008). Results for weeks 228 to the end of the test (week 332) showed increasing and equimolar concentrations of $\mathrm{Mg}$ and silica (see Figure 8 ) and slightly increasing concentrations of $\mathrm{Ni}, \mathrm{Al}$, and $\mathrm{K}$. The increasing $\mathrm{Mg}$ and silica concentrations could result from dissolution of a Mg-rich olivine (forsterite). In the last three weeks, the $\mathrm{pH}$ dropped from 4.15 to 3.86 , and $\mathrm{SO}_{4}$ concentrations increased from 0.8 to $1.2 \mathrm{mM}$; Fe concentrations decreased, likely due to solubility control by precipitation of Fe oxyhydroxide.

\subsection{Conclusions and Suggestions for Improvements}

\subsubsection{Summary and Conclusions}

We have shown that much more thorough interpretations of HCT results are possible, and understanding geochemical processes occurring in the tests may have transfer value to field conditions. Early-flush HCT concentrations are uniformly ignored in predictions of field $\mathrm{pH}$ and solution chemistry. Dissolution and flushing of acidic, metal-rich salts from field tests and waste piles can occur seasonally or after rain or snowmelt events every year and can have a strong effect on leachate and receiving stream chemistry. The first flush is a recurring theme in field observations, but the process occurs only in the early weeks of testing in the ASTM-type HCT experiment. Using steady-state rates in models that predict metal concentrations in streams will tend to ignore conditions that would produce the highest solute concentrations and have the highest potential to adversely affect water quality and aquatic biota. 
Another major issue in applying HCT results to field conditions is the difference in hydrologic and climatic conditions between the HCTs and the field. Weather conditions in the field rarely occur as weekly flushes such as in the HCTs, and flow paths in a waste or tailings pile can be substantially different from those in an HCT. Temperatures are controlled at a constant value in HCTs, but field temperatures can vary tremendously. The result can both speed up (hotter conditions) and slow down (cooler conditions) the weathering rates. Perhaps equally important is the heat output of oxidizing pyrite that can buffer the temperature within portions of a fullscale pile to higher values than average air temperatures.

Modifications to the ASTM HCT method affect leachate chemistry. The water:rock ratio, the particle size, and the volume of solution used likely have the strongest effects. Leachate concentrations would be higher with lower water:rock ratios (more material to dissolve in less water), smaller particle sizes (increased surface area), and lower solution volume (less dilution). As shown in our examples, the use of trickle versus flood leach methods also has an effect. To represent the field scale, the effect of a range of water:rock ratios would have to be determined, and leach conditions that mimicked site conditions would have to be obtained if one wished to estimate solution chemistry at given locations and times.Pilot-scale field tests should be run to close the gap between laboratory and actual field conditions. The extrapolation of early-flush and other laboratory results to the field must be conducted by those with appropriate expertise and consider solute generation, mineral oxidation and dissolution, seasonal and long-term climatic conditions, including infiltration rates, and transport in the field. 
Sulfide mineral oxidation rates are strongly dependent on the activity of Fe- and S-oxidizing bacteria, which are rarely monitored in HCTs. Therefore, HCTs may not be a predictive tool for estimating field rates when there is no information on microbial activity, with the possible exception of the time period when rapid sulfide mineral oxidation is clearly occurring. These rates are fast enough that they might provide some maximum rate estimates for the field. Further work along these lines is indicated.

"Steady-state" rates, which are conventionally selected using the last five weeks of humidity cell testing (e.g., Price, 2009), are often used to estimate long-term field weathering rates. Stable or steady-state rates are also used to predict the time to acid production. Our examination of tests from three projects with different geology and mineralization shows that the dominance of sulfide oxidation occurs over a limited period of time that, if tests are run for long enough, is not at the end of the test. In addition, the dissolution of metal sulfate salts, which can occur throughout the tests, occurs close to equilibrium conditions that are limited largely by the application of leaching solution. Steady-state conditions can occur at several time periods in a test that has run long enough, and then the dilemma is which plateau is the best one to use. There is no simple answer to this question. One cannot know a priori how long HCTs should be run, but from our examination of these three examples, clearly a year should be a minimum.

\subsubsection{Suggestions for Improvement}

Guidance is needed for more consistent interpretation of the results of HCTs. The guidance should rely on identifying the geochemical processes, the mineralogy, including secondary mineralogy and mineral coatings, the available surface area for reactions, and the influence of 
hydrologic processes on leachate concentrations in runoff, streams, and groundwater before mining begins. As noted by Price (2009), the prediction process should continue throughout the mine life-cycle.

The following suggestions may improve the HCT procedure, the evaluation of laboratory HCT results, and the use of test results in estimating leachate quality from mined materials:

- Redesign the current ASTM method to examine and allow for the use of early-flush concentrations in environmental models by eliminating early larger rinses, determining pre-test mineralogy, including sulfate salts, and conducting careful and complete weekly leachate analysis.

- Determine Eh and ferric and ferrous Fe concentrations analytically in samples, especially those with $\mathrm{pH}$ values below 4.0, to improve the understanding of geochemical reactions involving Fe.

- Measure the weekly variability in major, minor, and trace element chemistry for at least a year in HCTs that do not go acidic quickly to provide a data set that can better reflect the range of geochemical reactions that could occur under field conditions. Changing the climatic and hydrologic conditions to more closely match field conditions (long dry periods followed by more intense flushing, for example) should also be considered in parallel column studies.

- Plot major cations and anions in molar units and pH on a single graph to help understand the composition of soluble salts in HCT early flushes and geochemical behavior throughout the test.

- Evaluate the quality of analytical chemistry measurements for HCT leachate samples systematically, re-run the samples if the analytical results are outside acceptable $\mathrm{Cl}$ values, and make careful conductivity and ORP measurements at the time of leachate collection.

- Include information on HCT method modifications, including trickle versus flood leaching, and their possible effects. 
- Conduct matched laboratory and field leach tests to evaluate seasonal effects and assumptions about relationships between concentrations and surface area or mass of mined material being leached. The sampling frequency for field tests should be increased before, during, and after hydrologic events such as snowmelt and rainstorms.

- Use the maximum sulfide oxidation rates from HCTs as parametric inputs to waste-unit models that incorporate both flow and geochemistry when applying lab results to the field.

- Develop a reactive-transport model for HCTs, if sufficient data are collected. When reasonable success has been achieved, it could be applied to a small-scale pilot plot under field conditions to determine the relevance of HCT results.

Some of these suggestions parallel those of Parbhakar-Fox and Lottermoser (2015) and of Parbhakar-Fox et al. (2013), who emphasized the need for better mineralogical determinations before running kinetic tests. We endorse Lapakko's (2015) recommendations to use transparent models for environmental predictions, to compile a database of waste rock drainage concentrations, and to create a repository for environmental information collected by agencies and others throughout the life of a mine. We go further to suggest evaluating concentration-controlling phases, compiling and making publicly available information on environmental characterization, remediation successes and failures, and producing five-year reviews of the effectiveness of remedial technologies.

Considering the complications and uncertainties inherent in obtaining and applying the results from HCTs, it is difficult, if not impossible, to recommend them in isolation as a reliable guide for prediction of field-scale conditions. Instead, collecting and preparing appropriate materials that will be mined, conducting field-scale leach tests on these materials from early in the 
permitting process, and comparing the results to matched (?) laboratory leach tests would give a more reliable indication of the leachate quality expected under operational conditions.

Qualitative early predictions could be based on \% S, sulfide mineralogy, and carbonate mineralogy results. Laboratory-field scaling is a major unsolved problem that severely limits the usefulness of HCTs if not conducted rigorously and openly. Further research is warranted on comparisons of laboratory, pilot, and field tests to gain a better understanding of how to scale up laboratory- and pilot-scale results to actual field conditions.

Field pilot tests, if started early in the exploration/development process, could produce improvements in environmental behavior predictions. As mining progresses, waste seepage and receiving stream chemistry should be checked against laboratory and field test results and used to improve the design of treatment plants and mitigation measures.

\section{References}

Alpers, C.N., Nordstrom, D.K., Thompson, J.M., 1994. Seasonal variations in copper and zinc concentrations from Iron Mountain Mine. In Environmental Geochemistry of Sulfide Oxidation, C.N. Alpers and D.W. Blowes, eds., Am. Chem. Soc. Symp. Series 550: 324344.

ASTM (American Society for Testing Materials). 1996. Standard Test Method for Accelerated Weathering of Solid Materials Using a Modified Humidity Cell. D5744 - 96. West Conshohocken, PA: ASTM International. p. 13.

ASTM, 2001. Standard Test Method for Accelerated Weathering of Solid Materials Using a Modified Humidity Cell. D 5744-96. West Conshohocken, PA: ASTM International. pp. 257 - 269. (Reapproved).

ASTM, 2007. Standard Test Method for Laboratory Weathering of Solid Materials Using a Humidity Cell. D 5744-07e1. West Conshohocken, PA: ASTM International.

ASTM, 2013. Standard Test Method for Laboratory Weathering of Solid Materials Using a Humidity Cell. D 5744-13. West Conshohocken, PA: ASTM International. 
Atkins, A.S., 1978. Studies on the oxidation of sulphide minerals (pyrite) in the presence of bacteria. In Murr, L.E., Torma, A.E., and Brierley, J.A. (eds.) Metallurgical Applications of Bacterial Leaching and Related Microbiological Phenomena. Academic Press, New York, 403-426.

Ball, J.W., Nordstrom, D.K., 1991. User's Manual for WATEQ4F, with Revised Thermodynamic Database and Test Cases for Calculating Speciation of Major, Trace, and Redox Elements in Natural Waters. US Geol. Surv. Open-File Rep. 91-183.

Banwart, S.A., Evans, K., Croxford, S., 2002. Predicting mineral weathering rates at field scale for mine water risk assessment. In: Younger, P.L., Robins, N.S. (Eds.), Mine Water Hydrogeology and Geochemistry. The Geological Society of London, London, 137-157.

Baron, D, Palmer, C.D., 1996. Solubility of jarosite at $4-35^{\circ} \mathrm{C}$. Geochim. et Cosmochim. Acta, 60, 185-195.

Bigham, J.M., Nordstrom, D.K., 2000. Iron and aluminum hydroxysulfates from acid sulfate waters, In Alpers, C.N., Jambor, J.L., and Nordstrom, D.K., (eds.), Reviews in Mineralogy and Geochemistry, Vol. 40, Sulfate Minerals - Crystallography, Geochemistry, and Environmental Significance, P.H. Ribbe, Series Ed., Mineralogical Society of America, Washington, D.C., 351-403.

Blowes, D.W., Reardon, E.J., Cherry, J.A., Jambor, J.L., 1991. The formation and potential importance of cemented layers in inactive sulfide mine tailings. Geochim. Cosmochim. Acta 55, 965-978.

Bornhorst, T.J., Logsdon, M.J., 2016. Predicting future water-quality impacts from mining: A 52year-old field analog for humidity cell testing, Copperwood Deposit, Michigan. Econ. Geol., 111, 527-542.

Bureau of Land Management, 2013. Nevada Bureau of Land Management Rock Characterization and Water Resources Analysis Guidance for Mining Activities. Instruction Memorandum No. NV-2013-046. To: District Managers and Field Managers, Nevada. From: Amy Lueders, State Director. September 19.

Chopard, A., Benzaazoua, M., Plante, B., Bouzahzah, H., Marion, P., 2015. Kinetic tests to evaluate the relative oxidation rates of various sulfides and sulfosalts. $10^{\text {th }}$ International Conference on Acid Rock Drainage (ICARD) \& IMWA Annual Conference, Santiago, Chile. April 20-25. 10pp.

Downing, B., 2014. Kinetic testing data interpretation. In J.A. Jacobs, J.H. Lehr, and S.M. Testa (eds.) Acid Mine Drainage, Rock Drainage, and Acid Sulfate Soils: Causes, Assessments, Prediction, Prevention, and Remediation, John Wiley \& Sons, N.Y., 261-265.

Dutrizac, J.E., 2008. Factors affecting the precipitation of potassium jarosite in sulfate and chloride media. Metall. Mater. Trans. 39B, 771-783. 
Essington, M.E., 1991. Laboratory weathering of combusted oil shale. Jour. Environ. Quality 20, 794-801.

Golder Associates, Inc., 2005. Report on Buckhorn Mountain Project Humidity Cell Testing Week 40 Report. Submitted to: Crown Resources Corporation and Kinross Gold USA, Inc., Oroville, Washington. August 8, 144 pp.

Golder Associates, Inc., 2006. Technical Memorandum. Buckhorn Mountain Project - Humidity Cell Testing Addendum to Week 40 Report). To: Clyde Gillespie - Kinross Gold USA, Inc. from: Cheryl Ross and Rens Verburg. July 27, 70pp.

Hammarstrom, J.M., Seal II, R.R., Meier, A.L., Kornfeld, J.M., 2005. Secondary sulfate minerals associated with acid drainage in the eastern US: recycling of metals and acidity in surficial environments. Geochemistry of Sulfate Minerals: A Tribute to Robert O. Rye. Paper 2. Available: http://digitalcommons.unl.edu/usgsrye/2

Hickey III, R.J., 1990. The geology of the Buckhorn Mountain gold skarns, Okanogan County, Washington Journ. Idaho Acad. Sci. 26, 41-54.

Hickey III, R.J., 1992. The Buckhorn Mountain (Crown Jewel) gold skarn deposit, Okanogan County, Washington. Econ. Geol. 87,, 125-141.

Hollings, P., Hendry, M.J., Nicholson, R.V., Kirkland, R.A., 2001. Quantification of oxygen consumption and sulphate release rates for waste rock piles using kinetic cells: Cluff lake uranium mine, northern Saskatchewan, Canada. Appl. Geochem. 16, 1215-1230.

International Network for Acid Prevention (INAP), 2009. Global Acid Rock Drainage Guide (GARD Guide). Chapter 5. Predictions. Available: http://www.gardguide.com Accessed Dec. 2014.

Jambor, J.L., Nordstrom, D.K., Alpers, C.N., 2000. Metal-sulfate salts from sulfide mineral oxidation. In: Alpers, C.N., Jambor, J.L., and Nordstrom, D.K., (Eds.), Reviews in Mineralogy and Geochemistry, Vol., 40, Sulfate Minerals - Crystallography, Geochemistry, and Environmental Significance, P.H. Ribbe, Series Ed., Mineralogical Society of America, Washington, D.C., 303-350.

Jamieson, H.E., Robinson, C., Alpers, C.N., McCleskey, R.B., Nordstrom, D.K., Peterson, R.C., 2005a. Major and trace element composition of copiapite-group minerals and coexisting water from the Richmond mine, Iron Mountain, California. Chem. Geol. 215, 387-405.

Jamieson, H.E., Robinson, C., Alpers, C.N., Nordstrom, D.K., Poustovatov, A., Lowers, H.A., 2005b. The composition of coexisting jarosite-group minerals and water from the Richmond Mine, Iron Mountain, California. Can. Mineral. 43, 1225-1241. 
Janzen, M.P., Nicholson, R.V., Scharer, J.M., 2000. Pyrrhotite reaction kinetics: Reaction rates for oxidation by oxygen, ferric iron, and for nonoxidative dissolution. Geochim. Cosmochim. Acta 64, 1511-1522.

Kea Pacific Holding, Inc., 1993. Report on Geochemical Testing of Ore and Low Grade Ore, Crown Jewel Project. Prepared for Battle Mountain Gold Company. Submitted September.

King, P.L., McSween Jr, H.Y., 2005. Effects of $\mathrm{H}_{2} \mathrm{O}, \mathrm{pH}$, and oxidation state on the stability of Fe minerals on Mars. J. Geophys. Res. 110, E12S10. Available: http://onlinelibrary.wiley.com/wol1/doi/10.1029/2005JE002482/full

Kwong, Y.T.J., Swerhone, G.W., Lawrence, J.R., 2003. Galvanic sulphide oxidation as a metalleaching mechanism and its environmental implications. Geochem. Expl. Environ. Anal. 3, 337-343.

Lang, J.R., Gregory, M.J., Rebagliati, C.M., Payne, J.G., Oliver, J.L., Roberts, K., 2013. Geology and magmatic hydrothermal evolution of the giant Pebble porphyry copper-goldmolybdenum deposit, southwest Alaska. Econ. Geol. 108, 437-462.

Langman, J.B., Moore, M.L., Ptacek, C.J., Smith, L., Sego, D., Blowes, D.W., 2014. Diavik Waste Rock Project: Evolution of Mineral Weathering, Element Release, and Acid Generation and Neutralization during a Five-Year Humidity Cell Experiment. Minerals, 4, 257-278; doi:10.3390/min4020257. Available: www.mdpi.com/journal/minerals

Lapakko, K., 2015. Preoperational assessment of solute release from waste rock at proposed mining operations. Appl. Geochem. 57, 106-124.

Lapakko, K. A., Wessels, J. N., 1995. Release of acid from hydrothermal quartz-carbonate hosted gold-mine tailings. In Sudbury '95, Conference on Mining and the Environment, Sudbury, Ontario, May 28th - June 1st, 1995, 139-148.

Lapakko, K.A., White, W.W., 2000. Modification of the ASTM 5744-96 Kinetic Test. In Proceedings of Fifth International Conference on Acid Rock Drainage; Society for Mining, Metallurgy, and Exploration, Littleton, CO, USA, 631-639.

Lapakko, K.A., Berndt, M., 2003. Comparison of acid production from pyrite and jarosite. In Proc. of the Sixth International Conference on Acid Rock Drainage. Australasian Institute of Mining and Metallurgy, Publication Series No 3-2003 (CD ROM), 461-467.

Lapakko, K.A., Antonson, D.A., 2006. Pyrite oxidation rates from humidity cell testing of greenstone rock. In Proc. 2006, 7th ICARD, March 26-30, 2006, St. Louis MO. Amer. Soc. Mining Reclam., Lexington, KY, 1007-1025.

Lapakko, K., Olson, M., 2015. Scaling laboratory sulfate release rates to operational waste rock piles. $10^{\text {th }}$ ICARD/IMWA Annual meeting, Santiago, Chile, April 20-25. 15pp. 
Lapakko, K., Trujillo, E., 2015. Pyrite oxidation rates from laboratory tests on waste rock. $10^{\text {th }}$ ICARD/IMWA Annual meeting, Santiago, Chile, April 20-25. 14pp.

Lapakko, K., Antonson, D., Engstrom, J., 2004. Analytical screening of abandoned waste rock piles. Report to the US Army Corps of Engineers (Contract/Order No. DACW45-02-P0212), Minnesota Department of Natural Resources. June.

Lapakko, K. A., Engstrom, J., Antonson, D. A., 2006. Effects of particle size on drainage quality from three lithologies. In: Proc. 2006, $7^{\text {th }}$ ICARD, March 26-30, 2006, St. Louis MO. Amer. Soc. Mining Reclam., Lexington, KY,1026-1050.

Lapakko, K.A., Antonson, D., Leopold. E., Berndt, M.E., 2001. Mine Waste Characterization and Drainage Mitigation. Research Summary 2001. MN Dept. Natural Resources, Division of Lands and Minerals, Reclamation Section, St. Paul, MN. 58pp.

Maest, A.S., Kuipers, J.R., 2005. Predicting water quality at hardrock mines: Methods and models, uncertainties, and state-of-the-art. Prepared for Earthworks. Available: http://www.earthworksaction.org/publications.cfm?pubID = 212 .

McCleskey, R.B., Nordstrom, D.K., Ryan, J.N., 2011. Electrical conductivity method for natural waters. Appl. Geochem. 26, S227-S229.

McCleskey, R.B., Nordstrom, D.K., Ryan, J.N., Ball, J.W., 2012a. A new method of calculating electrical conductivity with applications to natural waters. Geochim. Cosmochm. Acta 77, 369-382.

McCleskey, R.B., Nordstrom, D.K., Ryan, J.N., 2012b. Comparison of electrical conductivity calculation methods for natural waters. Limnol. Oceanogr. Methods 10, 952-967.

McGregor, R.G., Blowes, D.W., 2002. The physical, chemical and mineralogical properties of three cemented layers within sulfide-bearing mine tailings. J. Geochem. Explor. 76, 195207.

McKibben, M.A., Barnes, H.L., 1986. Oxidation of pyrite in low temperature acidic solutions: Rate laws and surface textures. Geochim. Cosmochim. Acta 50, 1509-1520.

Minnesota Department of Natural Resources (MDNR), United States Army Corps of Engineers, and United States Forest Service, 2013. NorthMet Mining Project and Land Exchange. Supplemental Draft Environmental Impact Assessment (SDEIS). November.

Morin, K.A., Hutt, N.M., 2007. Scaling and equilibrium concentrations in minesite-drainage chemistry. MDAG Internet Case Study \#26. Available: www.mdag.com/case studies/cs26.html

Morin, K.A., 2013. Scaling factors of humidity-cell kinetic rates for larger-scale predictions. MDAG.com Internet Case Study \#38. Available: www.mdag.com/case studies/cs38.html 
Naldrett, A.J., Craig, J.R., Kullerud, G., 1967. The central portion of the Fe-Ni-S system and its bearing on pentlandite exsolution in iron-nickel sulfide ores. Econ. Geol. 62, 826-847.

Nicholson, R.V., Scharer, J.M., 1994. Laboratory studies of pyrrhotite oxidation kinetics, In: Alpers, C.N., Blowes, D.W. (Eds.), Environmental Geochemistry of Sulfide Oxidation, Am. Chem. Soc. Symp. Series 550, Amer. Chem. Soc., Washington D.C., 14-30.

Nicholson, R.V., Gillham, R.W., Reardon, E.J., 1988. Pyrite oxidation in carbonate-buffered solution: 1. Experimental kinetics. Geochim. Cosmochim. Acta 52, 1077-1085.

Nordstrom, D.K., 1982. Aqueous pyrite oxidation and the consequent formation of secondary iron minerals, In: Kittrick, J. A., Fanning, D. S., and Hossner, L. R. (Eds.), Acid Sulfate Weathering, Soil Sci. Soc. Am., Madison, WI, 37-56.

Nordstrom, D.K., 2008. Questa baseline and pre-mining ground-water quality investigation. 25. Summary of results and baseline and pre-mining ground-water geochemistry, Red River Valley, Taos County, New Mexico, 2001-2005. U.S. Geol. Surv. Prof. Paper 1728, 111 p.

Nordstrom, D.K., 2009. Acid rock drainage and climate change. J. Geochem. Explor. 100, 97104.

Nordstrom, D.K., 2011. Hydrogeochemical processes governing the origin, transport and fate of major and trace elements from mine wastes and mineralized rock to surface waters. Appl. Geochem. 26, 1777-1791.

Nordstrom, D.K., Munoz, J.L., 1994. Geochemical Thermodynamics, 2nd ed. Blackburn Press. Caldwell, NJ, 504 pp.

Nordstrom, D.K., Southam, G., 1997. Geomicrobiology of sulfide mineral oxidation. In: Banfield, J.F. and K.H. Nealson (Eds.), Geomicrobiology: Interactions between Microbes and Minerals 35, Rev. Mineral. Min. Soc. Am., Washington, D.C., 361-390.

Nordstrom, D.K., Alpers, C.N., 1999. Geochemistry of acid mine waters. In: G.S. Plumlee and M.J. Logsdon (Eds.), The Environmental Geochemistry of Mineral Deposits. Part A: Processes, Techniques, and Health Issues. Rev. Econ. Geol. 6A, Soc. Econ. Geol., Littleton, Colorado, 133-160.

Nordstrom D.K., Campbell, K.M., 2014. Modeling Low-Temperature Geochemical Processes. In: Drever, J.I. (Ed.) Treatise on Geochemistry, Holland H.D. and Turedian K.K. (Ex. Eds.), $2^{\text {nd }}$ Edition, vol. 7, 27-68.

Nordstrom, D.K., Jenne, E.A., Ball, J.W., 1979. Redox equilibria of iron in acid mine waters, In: Jenne, E.A., ed., Chemical Modeling in Aqueous Systems, Am. Chem. Soc. Symp. Series $93,51-80$.

Nordstrom, D.K., McCleskey, R.B., Ball, J.W., 2009. Sulfur geochemistry of hydrothermal waters in Yellowstone National Park: IV Acid-sulfate waters. Appl. Geochem. 24, 191-207. 
Olson, G.J., 1991. Rate of pyrite bioleaching by Thiobacillus ferrooxidans - Results of an interlaboratory comparison. Appl. Environ. Microbiol. 57, 642-644.

Parbhakar-Fox, A., Lottermoser, B.G., 2015. A critical review of acid rock drainage prediction methods and practices. Miner. Eng. 82, 107-124.

Parbhakar-Fox, A., Lottermoser, B., Bradshaw, D., 2013. Evaluating waste rock mineralogy and microtexture during kinetic testing for improved acid rock drainage prediction. Miner. Eng. 52, 111-124.

Parkhurst, D.L., Appelo, C.A.J., 2013. Description of input and examples for PHREEQC version 3: a computer program for speciation, batch-reaction, one-dimensional transport, and inverse geochemical calculations. Techniques and Methods 6-A43. Available: https://pubs.er.usgs.gov/publication/tm6A43.

PLP (Pebble Limited Partnership), 2011a. Pebble Project Environmental Baseline Document 2004 through 2008 (with updates in 2010). Chapter 11 and appendices. Geochemical Characterization, Bristol Bay Drainages. Prepared by SRK Consulting, Inc. for Pebble Limited Partnership. Available: https://pebbleresearch.files.wordpress.com/2014/03/ch 11 geochemistry bb.pdf

PLP, 2011b. Pebble Project Environmental Baseline Document 2004 through 2008 (with updates in 2010). Chapter 3. Geology and Mineralization, Bristol Bay Drainages. Prepared by Knight Piésold Ltd. for Pebble Limited Partnership. Available: https://pebbleresearch.files.wordpress.com/2014/03/ch 03 geology bb.pdf

PLP, 2011c. Pebble Project Environmental Baseline Document 2004 through 2008 (with updates in 2010). Chapter Procedures. Appendix F. Field Sampling Plans, Section 5.3. Prepared by SRK Consulting. Available: https://pebbleresearch.com/download/

Plumlee, G.S., Ludington, S., Vincent, K.R., Verplanck, P.L., Caine, J.S., Livo, K.E., 2009. Questa baseline and pre-mining ground-water quality investigation, 7. A pictorial record of chemical weathering, erosional processes, and potential debris-flow hazards in scar areas developed on hydrothermally altered rocks. U.S. Geol. Surv. Open-File Report 2009-1205.

Price, W.A., 2009. Prediction manual for drainage chemistry from sulphidic geologic materials. MEND Report 1.20.1. 579 pp. Report prepared by CANMET, Natural Resources Canada. Available: http://www.fs.usda.gov/Internet/FSE DOCUMENTS/stelprdb5336546.pdf.

Rimstidt, JD, Newcomb, WD., 1993. Measurement and analysis of rate data: The rate of reaction of ferric iron with pyrite. Geochim. Cosmochim. Acta 57, 1919-1934.

Ripley, E.M., Alawi, J.A., 1986. Sulfide mineralogy and chemical evolution of the Babbitt Cu-Ni deposit, Duluth Complex, Minnesota. Can. Mineral. 24, 347-369. 
Rutstein, M.S., 1980. Nickeloan melanterite from Sudbury Basin. Am. Mineral. 65, 968-969.

Sapsford, D.J., Bowell, R.J., Dey, M., Williams, K.P., 2009. Humidity cell tests for the prediction of acid rock drainage. Miner. Eng. 22, 25-36.

Scharer, J.M., Bolduc, L., Pettit, C.M., Halbert, B.E., 2000. Limitations of acid-base accounting for predicting acid rock drainage. Proc. $5^{\text {th }}$ Intern. Conf. Acid Rock Drainage, ICARD 2000, Soc. Min. Metall. Explor., 591-601.

Seal, R., Lapakko, K., Piatak, N., Woodruff, L., 2015. Reaction modeling of drainage quality in the Duluth Complex, Northern Minnesota, USA. $10^{\text {th }}$ ICARD/IMWA Annual meeting, Santiago, Chile, April 20-25. 10pp.

Sexsmith, K., MacGregor, D., Barnes, A., 2015. Comparison of actual and calculated lag times in humidity cell tests. $10^{\text {th }}$ ICARD/IMWA Annual meeting, Santiago, Chile, April 20-25. $10 \mathrm{pp}$.

SME (Society for Mining, Metallurgy \&Exploration), 2014. Volume 5. Techniques for Predicting Metal Mining Influenced Water. In: Management Technologies for Metal Mining Influenced Water. Williams, R.D. and Diehl, S.F. (Eds.). Appendix I.

Smith, L.J.D, Blowes, D.W., Jambor, J.L., Smith, L., Sego, D.C., Neuner, M., 2013a. The Diavik Waste Rock Project: Particle size distribution and sulfur characteristics of low-sulfide waste rock. Appl. Geochem. 36, 200-209.

Smith, L.J.D., Bailey, B.L., Blowes, D.W., Jambor, J.L., Smith, L., Sego, D.C., 2013b. The Diavik waste rock project: Initial geochemical response from a low sulfide waste rock pile. Appl. Geochem. 36, 210-221.

Smith, L.J.D., Moncur, M.C., Neuner, M., Gupton, M., Blowes, D.W., Smith, L., Sego, D.C., 2013c. The Diavik Waste Rock Project: Design, construction, and instrumentation of field-scale experimental waste-rock piles. Appl. Geochem. 36, 187-199.

SRK Consulting, 2007. RS53/RS42 - Waste Rock Characteristics/Waste Water Quality Modeling Waste Rock and Lean Ore - NorthMet Project - DRAFT. February/Draft 01, March 9, 2007. Available: https://www.leg.state.mn.us/docs/2015/other/150681/PFEISref 2/SRK\%202007b.pdf

Tremblay, G.A., Hogan, C.M., 2000. MEND Manual Volume 3 - Prediction MEND 5.4.2c Canadian Centre for Mineral and Energy Technology.

Tyson, R.M., Chang, L.L.Y., 1984. The petrology and sulfide mineralization of the Partridge River Troctolite, Duluth Complex, Minnesota. Can. Mineral. 22, 23-38. Available: http://rruff.info/doclib/cm/vol22/CM22 23.pdf

U.S. E.P.A. (Environmental Protection Agency), 2002. Guidance on Environmental Data Verification and Data Validation. EPA QA/G-8. Office of Environmental Information, 
Washington, D.C., EPA/240/R/004. November. 96 pp. Available:

https://www.epa.gov/sites/production/files/2015-06/documents/g8-final.pdf

Usher, B.H., 2009. Upscaling laboratory results for water quality prediction at underground collieries in South Africa's Highveld coalfields. Miner. Eng. 22, 43-56.

Wardrop, 2011. Preliminary assessment of the Pebble Project, Southwest Alaska. Report prepared for: Northern Dynasty Minerals Ltd. February. 579 pp. Available:

http://www.northerndynastyminerals.com/i/pdf/ndm/Pebble Project Preliminary\%20 Assessment\%20Technical\%20Report February\%2017\%202011.pdf

Washington State Department of Ecology, 2005. Buckhorn Mountain Supplemental Draft Environmental Impact Statement: Geochemistry, Surface Water, and Groundwater Quality Discipline Report. October 26. Prepared by URS Corporation. See: http://stlow.iii.com/search S17?/Ybuckhorn+mountain+draft+supplemental\&searchsco pe $=17 \& S O R T=D /$ Ybuckhorn+mountain+draft+supplemental\&searchscope $=17 \& S O R T=D$ \&criteria=17\&SUBKEY=buckhorn+mountain+draft+supplemental/1,2,2,B/frameset\&FF= Ybuckhorn+mountain+draft+supplemental\&searchscope=17\&SORT=D\&2,2,?saved=b14 $\underline{51548}$

Washington State Department of Ecology, 2014. Fact Sheet for NPDES Permit No. WA0052434, Buckhorn Mountain Mine. March 1. Available:

https://fortress.wa.gov/ecy/wqreports/public/f?p=publicparis:gen_permit docs:0::::P10 01 GENERAL PERMIT ID:733455 (download WA0052344_BuckhornFinalFactSheet_0227-2014.pdf)

White, W.W., Lapakko, K.A., Cox, R.L., 1999. Static-test methods most commonly used to predict acid-mine drainage: Practical guidelines for use and interpretation. In: G.S. Plumlee and M.J. Logsdon (Eds.), The Environmental Geochemistry of Mineral Deposits. Part A: Processes, Techniques, and Health Issues. Rev. Econ. Geol. 6A, Soc. Econ. Geol., Littleton, Colorado, 325-338.

Williams, R.D., S.F. Diehl (eds.), 2014. Techniques for Predicting Metal Mining Influenced Water. Soc. Min. Metall.Explor., Vol. 5, Appendix I, 119-120.

Younger, P.L., Banwart, S.A., Hedin, R.S., 2002. Mine Water Hydrology, Pollution, Remediation. Kluwer Academic Publishers, Dordrecht, Germany, 442 pp. 